\title{
Sequential Degradation of all and $\beta$ II Spectrin by Calpain in Glutamate or Maitotoxin-Stimulated Cells
}

\author{
Susan B. Glantz, Carol D. Cianci, Rathna lyer\#, Deepti Pradhan, Kevin K.W. Wang ${ }_{\star}^{\sim}$, and Jon \\ S. Morrow \\ Department of Pathology, Yale University School of Medicine, New Haven, Connecticut 06510; \\ \# CNS Biology, Pfizer Global Research and Development, 2800 Plymouth Road, Ann Arbor, MI \\ 48105 \\ Departments of Psychiatry and Neuroscience, McKnight Brain Institute of the University of Florida, \\ (P.O.Box100256), Gainesville, FL 32610, USA
}

\begin{abstract}
Calpain-catalyzed proteolysis of $\alpha$ II-spectrin is a regulated event associated with neuronal long-term potentiation, platelet and leukocyte activation, and other processes. Calpain proteolysis is also linked to apoptotic and non-apoptotic cell death following excessive glutamate exposure, hypoxia, HIVgp120/160 exposure, or toxic injury. The molecular basis for these divergent consequences of calpain action, and their relationship to spectrin proteolysis, is unclear. Calpain preferentially cleaves $\alpha$ II spectrin in vitro in repeat 11 between residues $\mathrm{Y}_{1176}$ and $\mathrm{G}_{1177}$. Unless stimulated by $\mathrm{Ca}^{++}$and calmodulin $(\mathrm{CaM}), \beta \mathrm{II}$ spectrin proteolysis in vitro is much slower. We identify additional unrecognized sites in spectrin targeted by calpain in vitro and in vivo. Bound $\mathrm{CaM}$ induces a second $\alpha$ II spectrin cleavage at $\mathrm{G}_{1230} * \mathrm{~S}_{1231}$. $\beta$ II spectrin is cleaved at four sites. One cleavage only occurs in the absence of $\mathrm{CaM}$ at high enzyme-to-substrate ratios near the $\beta \mathrm{II}$ spectrin $\mathrm{COOH}$-terminus. $\mathrm{CaM}$ promotes $\beta$ II spectrin cleavages at Q1440*S1441, S1447*Q1448, and L1482*A1483. These sites are also cleaved in the absence of $\mathrm{CaM}$ in recombinant $\beta \mathrm{II}$ spectrin fusion peptides, indicating that they are probably shielded in the spectrin heterotetramer and become exposed only after CaM binds $\alpha$ II spectrin. Using epitope-specific antibodies prepared to the calpain cleavage sites in both $\alpha \mathrm{II}$ and $\beta$ II spectrin, we find in cultured rat cortical neurons that brief glutamate exposure (a physiologic ligand) rapidly stimulates $\alpha$ II spectrin cleavage only at $\mathrm{Y}_{1176} * \mathrm{G}_{1177}$, while $\beta$ II spectrin remains intact. In cultured SH-SY5Y cells that lack an NMDA receptor, glutamate is without effect. Conversely, when stimulated by calcium influx (via maitotoxin), there is rapid and sequential cleavage of $\alpha I I$ and then $\beta I I$ spectrin, coinciding with the onset of non-apoptotic cell death. These results identify: i) novel calpain target sites in both $\alpha$ II and $\beta$ II spectrin; ii) trans-regulation of proteolytic susceptibility between the spectrin subunits in vivo; and iii) the preferential cleavage of $\alpha$ II spectrin vs. $\beta$ II spectrin when responsive cells are stimulated by engagement of the NMDA receptor. We postulate that calpain proteolysis of spectrin can activate two physiologically distinct responses: one that enhances skeletal plasticity without destroying the spectrin-actin skeleton, characterized by preservation of $\beta I I$ spectrin; or an alternative response closely correlated with nonapoptotic cell death and characterized by proteolysis of $\beta I I$ spectrin and complete dissolution of the spectrin skeleton.
\end{abstract}

\section{Keywords}

cytoskeleton; proteolysis; necrosis; cell death; glutamate; fodrin

\footnotetext{
* To whom correspondence should be addressed. tel: 203-785-3624 Fax 203-785-7037 E-mail: jon.morrow@ yale.edu.
} 
Spectrin is the major component of the cytoskeletal network associated with the plasma membrane of vertebrate cells (for reviews 1,2,3). While seven spectrin genes exist, encoding two variants of an alpha spectrin and five beta spectrins, the most common form of this protein is a heterotetramer of $\alpha \mathrm{II}, \beta \mathrm{II}$ spectrin. Together with actin and a host of adapter proteins, spectrin controls the distribution of many integral and peripheral membrane proteins, and possibly also the distribution of certain phospholipids. Mutations in spectrin or its associated adapter proteins typically destabilize the membrane, and their absence is often embryonic lethal $(4,5)$. Calcium-dependent proteolytic modification of aII-spectrin by any of several calpain proteases is linked to platelet activation (6), neutrophil degranulation (7), the onset of longterm potentiation in hippocampal neurons $\left(8^{-} 11\right)$, dendritic and post synaptic density remodeling $\left(12^{-} 14\right)$, crystalline lens maturation (15), and receptor-mediated endocytosis (16). Calpain activation occurs in response to fibrinogen binding to the integrin glycoprotein IIb-IIIa in platelets $(6,17)$ and to NMDA-stimulation of responsive neurons $\left(9,18^{-} 21\right)$. Beyond these putative physiologic processes, calpain processing of $\alpha$ II-spectrin also follows hypoxic or ischemic injury (22-34). In the brain, calpain activation is associated with excitatory amino acid toxicity, as occurs experimentally after treatment with kainate or NMDA $\left(18,19,35^{-}\right.$ 37 ), and may be accentuated by the action of HIV-1 gp120/160 (38-40). Calpain-cleavage of spectrin has been observed during apoptosis in monocytic U937 cells (41) and in neurons $(42,43)$. The molecular basis for these divergent consequences of calpain action, and their relationship to spectrin proteolysis, is unclear.

Previously this laboratory determined that a central region within repeat unit 11 of $\alpha$ II spectrin is hypersensitive to a variety of proteases, including $\mu$-calpain (44), and demonstrated that the preferred site of calpain cleavage is between $\mathrm{Y}_{1176} * \mathrm{G}_{1177}$, immediately adjacent to the calmodulin binding domain in this protein $(45,46)$. Epitope-specific antibodies recognizing the in vitro generated cleavage fragments established that cleavage also occurs at this site in vivo (47), and mutational analysis revealed that the specificity of calpain for this site is determined by complex conformational rather than linear sequence determinants (48). The sensitivity of this site to cleavage is regulated at the substrate level by the phosphorylation of $\mathrm{Y}_{1176}$, a process mediated by src-family kinases and low-molecular-weight phosphotyrosine phosphatase (LMW-PTP) $(49,50)$.

Calpain also cleaves $\beta$ II spectrin, but at least in vitro does so efficiently only when $\mathrm{CaM}$ is bound to the $\alpha \mathrm{II}$ subunit in the $\alpha \mathrm{II} / \beta \mathrm{II}$ heterodimer (46), an event that induces a substantial conformational change in sequences associated with the CaM-binding site (51). Other cleavages of $\beta$ II spectrin by calpain also exist $(52,53)$, yet beyond the identification in fusion peptides of a susceptible site near the $\mathrm{COOH}$ terminus $\left(\mathrm{A}_{2067}\right)$ of $\beta \mathrm{II}$ spectrin $(53)$, the precise locus of any calpain-cleavage site in $\beta$ II spectrin or its CaM-dependency is unknown. In vitro studies have established a complex relationship between calpain cleavage of spectrin, $\mathrm{Ca}^{++}, \mathrm{CaM}$ binding, and the ability of spectrin to oligomerize, bind actin, and bind to membranes $(52,54)$. These studies suggest that calpain cleavage of aII spectrin converts this molecule into a reversible $\mathrm{Ca}^{++}$and CaM-regulated actin cross-linking protein, whereas coincident calpain-cleavage of the $\beta$ II subunit irreversibly disassembles the spectrin-actin cortical membrane skeletal lattice. Thus, two calcium-dependent processes, calmodulin binding and calpain proteolysis, unless suppressed by tyrosine phosphorylation of $\alpha$ II spectrin $(49,50)$, act synergistically to regulate the proteolysis of spectrin and the organization and integrity of the cortical membrane skeletal lattice.

In the present study, we identify a second calmodulin-regulated site targeted by calpain in $\alpha$ II spectrin, and three novel sites of cleavage in $\beta I I$ spectrin. Using subunit and cleavage specific antibodies to $\alpha \mathrm{II}$ and $\beta \mathrm{II}$ spectrin, we find that glutamate stimulation of cortical neurons preferentially induces $\alpha$ II spectrin cleavage as a very early event, while, in non-glutamate 
responsive SH-SY5Y cells, spectrin is unaffected by glutamate exposure. When calcium is introduced directly into cells by maitotoxin treatment, delayed cell death ensues on a timescale that correlates with complete calpain-mediated breakdown of both $\alpha \mathrm{II}$ and $\beta I \mathrm{II}$ spectrin, with $\alpha$ II cleavage again preceding that of $\beta$ II spectrin. These findings together with the earlier data cited above indicate that $\alpha$ II spectrin cleavage per se is not cell lethal (21), and suggest that as when spectrin is cleaved by caspase 3 during apoptosis (55), the advent of $\beta I I$ subunit cleavage marks an irreversible transition in the cortical cytoskeleton that may contribute to impaired cell viability.

\section{MATERIALS AND METHODS}

\section{Protein preparation and expression of recombinant peptides}

Fresh calf brain was obtained from a local abattoir and was washed in cold $0.32 \mathrm{M}$ sucrose prior to homogenization. Bovine $\alpha \mathrm{II} / \beta \mathrm{II}$ spectrin was purified from demyelinated brain membranes by low ionic strength extraction followed by gel filtration on Sephacryl S-500 HR $(56,57)$. Recombinant peptides representing various regions of $\alpha I I$ and $\beta I I$ spectrin were prepared as glutathione-S-transferase (GST) fusion peptides in E. coli strains CAG-456 and W3110, and purified using glutathione-agarose $(48,58)$. Purified spectrin and fusion proteins were stored in $40 \mathrm{mM}$ Tris $\mathrm{pH} 7.5,50 \mathrm{mM} \mathrm{NaCl}, 0.5 \mathrm{mM}$ DTT, $0.1 \mathrm{mM}$ Pefabloc, $0.1 \mathrm{mM}$ Benzamidine. Purified porcine erythrocyte $\mu$-calpain was acquired from Nacalai Tesque, Inc. in Kyoto, Japan. CaM was from Sigma.

\section{Antibodies}

PAb RAF-A is a well-documented polyclonal rabbit antibody that recognizes $\alpha$ II-spectrin (46, 59). Alternatively, for some experiments, the monoclonal $\alpha$ II spectrin antibody from Chemicon (\#1622) was also used. PAb-10D, is a rabbit polyclonal, was prepared to a recombinant peptide representing residues 1676 to 2204 of human $\beta I$ II spectrin, corresponding to sequence repeat unit 13 to the middle of the $\mathrm{COOH}$-terminal domain III (58). For the PAb's $\alpha$-bdp1 and $\alpha$-bdp2, the synthetic peptides CQQEVY and GMMPRC respectively were each coupled to keyhole limpet hemocyanin (KLH) via the cysteine residue using $\mathrm{m}$ maleimidobenzoyl-N-hydroxysuccinimide ester, and injected into New Zealand White rabbits in complete Freund's adjuvant following previous protocols (59). For the PAb $\beta I I-B D P 1$, the synthetic peptide CGIEELQ was similarly coupled to maleimide activated KLH (Pierce); IgY was raised in white leghorn chickens and purified from egg yolk by Aves Labs, Inc., Tigand, OR. All cleavage-specific rabbit antibodies were affinity purified against their respective ligands using antigen-coupled Sepharose in which the peptide was linked via its terminal cysteine. Antibodies raised in chickens were affinity purified against peptide coupled by its cysteine to sulfolink coupling gel (Pierce, Inc.) (60).

\section{Calpain Digestion}

Unless otherwise specified, $10 \mu \mathrm{g}$ of purified spectrin was digested by $0.03 \mu \mathrm{g}$ of $\mu$-calpain in digestion buffer containing $20 \mathrm{mM}$ Tris $\mathrm{pH} 7.5,25 \mathrm{mM} \mathrm{NaCl}, 0.15 \mathrm{mM}$ total $\mathrm{CaCl}_{2}$, and 10 $\mathrm{mM}$ DTT, with or without $5 \mu \mathrm{M} \mathrm{CaM}(25 \mu \mathrm{l}$ total volume $)$ at $25^{\circ} \mathrm{C}$. Proteolysis was terminated by the addition of $5 \mathrm{x}$ SDS-PAGE solubilizing buffer at $95^{\circ} \mathrm{C}$ for 5 minutes $(61)$, or at $37^{\circ} \mathrm{C}$ for 15 minutes for samples used for microsequencing. Digestion patterns were analyzed by SDSPAGE, followed either by Coomassie blue staining or by transfer to Immobilon-P membranes (Millipore) for immunoblot detection or $\mathrm{NH}_{2}$-terminal amino acid sequencing. The apparent sizes of the digestion products were calculated based on migration of the standard BioRad ${ }^{\circledR}$ High Molecular Weight Markers. Purified fusion peptides were similarly treated. In the case of the GST- $\beta \mathrm{II}_{8-\mathrm{C} \Delta}$ peptide, $70 \mu \mathrm{g}$ protein was digested with $0.3 \mu \mathrm{g}$ calpain; digestion was halted by a 10-fold molar excess of EDTA (relative to total calcium). After digestion GST containing fragments were adsorbed with $5 \mathrm{mg}$ of glutathione-agarose in the presence of 0.1 
$\mathrm{mg} / \mathrm{ml} \mathrm{BSA}$ by overnight incubation at $4^{\circ} \mathrm{C}$ so as to facilitate the isolation of the GST-free $\mathrm{COOH}$-terminal digestion products for sequencing.

\section{Calpain activation in cultured cells}

Cerebral cortices were dissected from E16 to E17 day old Sprague-Dawley rat fetuses and hippocampi were dissected from E20-21 day old fetuses, using sterile technique and triturated to suspend the cells. Cells were plated at a density of $6-7 \times 10^{5}$ cells per $35 \mathrm{~mm}$ diameter dish. All culture dishes were pre-coated with poly-D-lysine $(20 \mu \mathrm{g} / \mathrm{ml}$; $\mathrm{Mr} 30,000-70,000)$. Cultures were grown at $37^{\circ} \mathrm{C}, 5 \% \mathrm{CO}_{2}$ in DMEM/F-12 medium supplemented with $30 \mathrm{mM}$ glucose, B-27 serum-free supplement, $40 \mathrm{U}$ penicillin $\mathrm{G}$ sodium per $\mathrm{ml}$ and $40 \mu \mathrm{g}$ streptomycin sulfate per $\mathrm{ml}$ for 4 to 5 days, after which the medium was changed to Neurobasal Medium supplemented with B27, $0.5 \mathrm{mM}$ glutamine, $10 \mathrm{U}$ penicillin $\mathrm{G}$ sodium per $\mathrm{ml}$ and $10 \mu \mathrm{g}$ streptomycin sulfate per ml. Cultures were maintained by replacing half of the medium with fresh medium twice weekly. Tissue culture media and supplements were obtained from Gibco BRL. Experiments were performed on cortical and hippocampal cultures after two to three weeks in vitro. These cultures consisted of greater than $90 \%$ neurons. Cells were rinsed once with phosphate buffered saline, and once with $\mathrm{Mg}^{++}$-free Krebs' Ringer medium (20 mM HEPES, $1 \mathrm{mM} \mathrm{Na}_{2} \mathrm{HPO}_{4}, 128 \mathrm{mM} \mathrm{NaCl}, 5 \mathrm{mM} \mathrm{KCl}, 2.7 \mathrm{mM} \mathrm{CaCl}_{2}, 10 \mathrm{mM}$ glucose, $\mathrm{pH}$ 7.2). Then they were incubated in $\mathrm{Mg}^{++}$-free Ringer medium containing $5 \mu \mathrm{M}$ glycine, with or without glutamate $(50-400 \mu \mathrm{M})$ or NMDA $(50 \mu \mathrm{M})$, at $37^{\circ} \mathrm{C}, 5 \% \mathrm{CO}_{2}$. In the case of the 24 hour time course, after incubating for 30 minutes with $50 \mu \mathrm{M}$ NMDA in $\mathrm{Mg}^{++}$-free Krebs' Ringer medium containing $5 \mu \mathrm{M}$ glycine, cells were rinsed to remove the NMDA and the Krebs' Ringer medium was replaced with conditioned supplemented Neurobasal Medium for the remainder of the experiment. $20 \mu \mathrm{M}$ MK801 (from $10 \mathrm{mM}$ stock in water) and $100 \mu \mathrm{g} / \mathrm{ml}$ Calpeptin (from $50 \mathrm{mg} / \mathrm{ml}$ DMSO stock) were applied to cultures prior to the addition of glutamate (from $100 \mathrm{mM}$ stock) or NMDA (from $100 \mathrm{mM}$ stock in $0.01 \mathrm{~N} \mathrm{NaOH}$ ). Controls received equivalent volumes of diluents. At the end of the experimental time period, the buffer was removed and cells were extracted with $150 \mu \mathrm{l}$ of $1 \mathrm{x}$ Laemmli SDS-PAGE sample buffer containing $150 \mathrm{mM} \mathrm{NaCl}, 2 \mathrm{mM}$ EDTA, $2 \mathrm{mM}$ EGTA, $0.4 \mathrm{mM}$ DTT, $1 \mathrm{mM}$ Pefabloc, $20 \mu \mathrm{g} /$ $\mathrm{ml}$ leupeptin, $1 \mathrm{mM}$ benzamidine, $10 \mu \mathrm{g} / \mathrm{ml}$ aprotinin. Samples were heated to $100^{\circ} \mathrm{C}$ for 10 minutes..

For maitotoxin experiments, SH-SY5Y cells were grown in MEM/F12 (1:1) with non-essential amino acids which was supplemented with $10 \%$ fetal bovine serum, $2 \mathrm{mM}$ glutamine, $50 \mathrm{U} / \mathrm{ml}$ penicillin G sodium and $50 \mu \mathrm{g} / \mathrm{ml}$ streptomycin sulfate at $37^{\circ} \mathrm{C}, 5 \% \mathrm{CO} 2$. Experiments were performed in $35 \mathrm{~mm}$ dishes containing cultures that were $2 / 3$ to $3 / 4$ confluent. The medium was replaced by $2 \mathrm{ml}$ serum-free medium containing $2 \mathrm{mM}$ glutamine to which the treatments were added. Calpain inhibitor ( $100 \mu \mathrm{g} / \mathrm{ml}$ Calpeptin from $50 \mathrm{mg} / \mathrm{ml}$ DMSO stock) and caspase inhibitor ( $100 \mu \mathrm{M}$ Z-D-DCB from $50 \mathrm{mM}$ stock in DMSO) were added to the medium 15 minutes prior to treatment with $0.03 \mathrm{nM}$ or $0.04 \mathrm{nM}$ Maitotoxin (from $2 \mu \mathrm{M}$ stock in Ethanol) followed by various times of incubation at $37^{\circ} \mathrm{C}, 5 \% \mathrm{CO}$. Vehicle controls received equivalent volumes of Ethanol and/or DMSO. At the end of the treatment period, the medium containing floating cells was centrifuged @ 1000 rpm for 2 minutes and rinsed once with PBS. The remaining adherent cells on the dish were rinsed once with PBS and pooled with the medium containing the floating cells prior to centrifugation. The cells remaining on the dish were extracted with $150 \mu \mathrm{l}$ 1x Laemmli SDS-PAGE sample buffer containing inhibitors, as was used for the primary cultures, and this extract was combined with the floating cell pellet and heated to $100^{\circ} \mathrm{C}$ for 10 minutes. In parallel experiments, similarly treated SH-SY5Y cells were analyzed for evidence of cell death by flow cytometry. Cells collected as above were resuspended in $300 \mu \mathrm{l}$ PBS containing $2 \%$ goat serum PBS/GS followed by the addition of 300 $\mu \mathrm{l}$ PBS/GS containing $8 \mu \mathrm{M}$ Ethidium-1 (final concentration of $4 \mu \mathrm{M}$ ). After filtration through 
a $35 \mu \mathrm{M}$ nylon mesh filter (BD Falcon) cells were counted by flow cytometry 10 minutes after the addition of Ethidium-1, 30 minutes after termination of the maitoxin treatment.

\section{Other}

Protease inhibitors used were Pefabloc SC (Centerchem Inc.), Benzamidine (Sigma), Leupeptin (Sigma), Pepstatin A (Boehringer Mannheim), and Aprotinin (Sigma). NMDA, glutamate, and MK801 were purchased from RBI. Calmodulin (bovine brain) and maitotoxin were from Sigma, calpeptin from Calbiochem, and Ethidium-1 from Molecular Probes. Transfers to Immobilon-P PVDF membrane (Millipore, Inc.) for Western blotting were performed in $25 \mathrm{mM}$ Tris, $192 \mathrm{mM}$ glycine, $10 \%$ methanol. Immunoblots were blocked with milk buffer ( $5 \%$ Carnation ${ }^{\circledR}$ Nonfat Dry Milk, $0.1 \%$ bovine serum albumin Fraction V (Sigma), $0.02 \%$ sodium azide in $1 \mathrm{x}$ phosphate buffered saline, $\mathrm{pH} 7.4$ ) for one hour, incubated in primary antibody diluted in milk buffer for one hour, rinsed twice then washed $1 \mathrm{x} 15$ minutes and $2 \mathrm{x}$ 5 minutes in phosphate buffered saline pH 7.4 containing $0.1 \%$ Tween 20 (PBS-Tween). After incubation in secondary antibody (goat anti-rabbit horse-radish peroxidase from Pierce, or rabbit anti-chicken horse-radish peroxidase from Accurate Chemical) diluted in PBS-Tween or milk buffer, respectively, for one hour followed by four 5-minute washes, enzymatic activity was detected by chemiluminescence (ECL, Amersham) using Amersham Hyperfilm ${ }^{\circledR}$, or alternatively was detected colorimetrically with alkaline phosphatase. Estimation of protein was by $\mathrm{OD}_{280}$ and by BCA assay (Pierce). Microsequencing of digested peptides was performed using an Applied Biosystems Protein sequencer, or alternatively by Yale's Keck Biotechnology Resource Laboratory using similar equipment. Densitometry of gels and fluorgrams were performed on digital images on a Macintosh computer using the public domain NIH Image or J-image programs (developed at the U.S. National Institutes of Health and available on the Internet at ://rsb.info.nih.gov/nih-image/).

\section{RESULTS}

\section{Calmodulin enhances the susceptibility of both $\alpha$ ll and $\beta$ II spectrin to $\mu$-calpain}

The CaM binding domain in $\alpha$ II spectrin flanks the site of calpain cleavage and undergoes a substantial conformational reordering upon CaM binding (51). Both subunits of spectrin are more susceptible to cleavage when $\mathrm{CaM}$ is bound $(45,46)$. Figures 1 and 2 reveal several additional features of this phenomenon; a summary of all spectrin breakdown products (BDP's) is presented in Table I.

In the absence of calmodulin, the major cleavage product of spectrin appears at $\approx 150 \mathrm{kD}$ $(\alpha I I-B D P 150)$. Based on its antibody reactivity, this fragment arises exclusively from $\alpha$ II spectrin, and in the absence of CaM is the only site of $\alpha \mathrm{II}$ spectrin cleavage. Previous peptide mapping studies have established that the $150 \mathrm{KD}$ band contains both halves of the $\alpha$ II subunit (45), these are not resolved by SDS-PAGE despite their differences in true $\mathrm{MW}$. $\mathrm{NH}_{2}$-terminal microsequencing of $\alpha$ II-BDP150 confirmed the cleavage between $\mathrm{Y}_{1176}{ }^{*} \mathrm{G}_{1177}$ (Table I and 45). Other experiments demonstrated that milli-calpain also cleaves $\alpha$ II spectrin at this site (data not shown). In the absence of CaM, two $\beta$ II spectrin BDP's were sub-stoichiometrically generated, yielding $\beta I I-B D P 220$ and $\beta I I-B D P 215$. These appear to be unfavorable cleavages, presumably with a high $\mathrm{K}_{\max }$, since they are quantitatively significant only at high enzyme/ substrate ratios as shown in Figure 2. Thus, to achieve quantitative cleavage of $\beta$ II spectrin to $\beta$ II-BDP215 under the conditions used here requires molar ratios of calpain-to-spectrin of 1:6, whereas efficient cleavage of aII spectrin is achieved with at least an order of magnitude less enzyme (44). Microsequencing detected no reliable $\mathrm{NH}_{2}$-terminal sequence information from $\beta I I-B D P 215$. 
In earlier studies, we established that CaM bound to the $\alpha$ II-subunit enhances both the rate of $\alpha \mathrm{II}-\mathrm{BDP} 150$ generation and the rate of $\beta \mathrm{II}-$ subunit cleavage (46). As reported here, CaM also renders several new sites in $\alpha$ II and $\beta$ II spectrin susceptible to cleavage (Figure 1). In $\alpha$ II spectrin, CaM-binding generates a new susceptibility to proteolysis at $\mathrm{G}_{1230} * \mathrm{~S}_{1231}$, liberating the CaM binding domain and converting $\alpha$ II-BDP150 to $\alpha$ II-BDP145 (Table I). It also appears that $\alpha$ II-BDP150', the NH2-terminal half of aII spectrin, undergoes a second cleavage to generate $\alpha$ II-BDP145', since the entire band at $150 \mathrm{kD}$ disappears coincident with the generation of the band at $145 \mathrm{kD}$ (Figure 2). Since only a single $\mathrm{NH}_{2}$-terminal sequence was detected by microsequencing of the $145 \mathrm{kD}$ band, it is likely that $\alpha \mathrm{II}-\mathrm{BDP} 145^{\prime}$ is generated from aII-BDP150' by additional cleavage near its $\mathrm{COOH}$-terminus.

In $\beta$ II spectrin, prominent calpain cleavage products appear in the presence of $\mathrm{CaM}$ near 166 $\mathrm{kD}(\beta \mathrm{II}-\mathrm{BDP} 166, \beta \mathrm{II}-\mathrm{BDP} 163$, and $\beta \mathrm{II}-\mathrm{BDP} 159)$, and $120 \mathrm{kD}$ ( $\beta \mathrm{II}-\mathrm{BDP} 120$ and $\beta \mathrm{II}-\mathrm{BDP} 116)$ (Figures 1,2). While numerous spectrin BDP's have been observed in earlier studies with CaM, they have not been characterized $(44,46)$. $\mathrm{NH}_{2}$-terminal sequences were not detected for the $\beta$ II-BDP166-159 products; these fragments were also not reactive with PAb 10D that is directed against sequence downstream of repeat unit 13 (see methods). Together, these data establish the origin of $\beta$ II-BDP $166-159$ from the $\mathrm{NH}_{2}$-terminal portions of $\beta$ II spectrin.

Increasing E/S ratios favored the generation of $\beta$ II-BDP159 at the expense of $\beta$ II-BDP166 and $\beta \mathrm{II}-\mathrm{BDP} 163$, indicating that once cleavage had occurred, additional sites near the $\mathrm{COOH}-$ terminus of $\beta$ II-BDP166 must become susceptible to calpain (also see results below with the $\beta I I-b d p 1$ antibody). While $\beta$ II-BDP120 and $\beta$ II-BDP116 stained poorly by Coomassie blue, they were readily detected by immunoblotting with PAb-10D (Figure 1). These two fragments differed in their $\mathrm{NH}_{2}$-termini. Sequencing of $\beta$ II-BDP120 yielded cleavage sites of $\mathrm{Q}_{1440} * \mathrm{~S}_{1441}$ and $\mathrm{S}_{1447} * \mathrm{Q}_{1448}$. Sequencing of $\beta$ II-BDP116 did not yield a discrete sequence, and consisted of an apparent mixture of closely related peptides with $\mathrm{NH}_{2}$-termini derived from a series of cleavages between $\mathrm{F}_{1467} * \mathrm{M}_{1468}$ and $\mathrm{L}_{1482} * \mathrm{~A}_{1483}$. The origins for this variability in the terminus of $\beta$ II-BDP116 were not determined. Finally, two novel BDP's were detected at $\approx 62$ and $\approx 58 \mathrm{kD}$ ( $\beta$ II-BDP62 and $\beta$ III-BDP58). These were most apparent after Western blotting with $\mathrm{PAb}-10 \mathrm{D}$, revealing their origin from the $\mathrm{COOH}$-terminal half of $\beta \mathrm{II}$ spectrin.

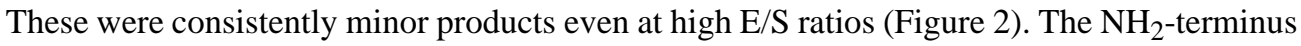
of $\beta$ II-BDP58 was derived from cleavage between $\mathrm{L}_{1482} * \mathrm{~A}_{1483}$, similar to one of the cleavages responsible for $\beta$ II-BDP116. Thus, $\beta$ II-BDP58 must be derived from $\beta$ II-BDP116 by an additional COOH-terminal directed cleavage (Table I). The cleavage responsible for the genesis of $\beta$ II-BDP62 was not determined.

\section{Recombinant spectrin peptides are cleaved by calpain at the native sites}

Previous studies established that $\alpha$ II spectrin GST-fusion peptides containing repeat unit 11 and the $\mathrm{CaM}$ binding domain are readily cleaved by $\mu$-calpain (48). In the current study, microsequencing of the calpain cleavage products derived from digesting GST- $\alpha \mathrm{II}_{9-12}$ (Figure 3), a fusion peptide encompassing repeat units 9 to 12 (see Fig. 8), established that this peptide is cleaved at a site identical to that of the native $\alpha$ II spectrin heterotetramer (Table I). Calpain did not appreciably digest peptides GST- $\alpha \mathrm{II}_{13-18}$ and GST- $\alpha \mathrm{II}_{18-\mathrm{C}}$ (data not shown). Calpain digestion of GST- $\beta \mathrm{II}_{8-\mathrm{C} \Delta}$, a fusion peptide encompassing $\beta \mathrm{II}$ spectrin repeat units 8 to 17 and a portion of domain III (58), yielded four cleavage fragments at $\approx 92, \approx 88, \approx 70$, and $\approx 47 \mathrm{kD}$ (Figure 3 ). Because the $\approx 70$ and $\approx 47 \mathrm{kD}$ products are retained on a glutathione affinity column, they must contain GST and thus arise from the $\mathrm{NH}_{2}$-terminal portion of the peptide.

The prominent non-GST containing band at $\approx 92 \mathrm{kD}$ displayed two $\mathrm{NH}_{2}$-terminal sequences that were out of register by seven residues. These results were identical to the $\mathrm{NH}_{2}$-terminal sequences detected for $\beta$ II-BDP120 (Table I). The susceptibility of the $\beta$ II $8-\mathrm{C} \Delta$ peptide to calpain could not be accounted for by an artifact of its folding, since it had the same $\alpha$-helical 
content as intact spectrin ( $\approx 70 \%$ ) by CD measurement (data not shown), and a similar peptide ( $\beta$ II 8-13) also gave the same digestion pattern (data not shown). The minor non-GST containing $88 \mathrm{kD}$ fragment yielded $\mathrm{NH}_{2}$-terminal sequences identical to those of $\beta$ II-BDP5 8 and $\beta I I-B D P 116$. Finally, the calpain cleavage patterns of GST- $\beta I_{N-4}$ and GST- $\beta I_{16-C}$ were examined to better understand the susceptibility of the ends of $\beta I I$ spectrin to calpain cleavage. No digestion products were detected in the GST- $\beta \mathrm{II}_{\mathrm{N}-4}$ peptide (data not shown). Calpain generated two prominent digestion products at $\approx 44$ and $45 \mathrm{kD}$ from GST- $\beta \mathrm{II}_{16-C}$. Both of these products were recognized by anti-GST antibody (data not shown), indicating their origin from the $\mathrm{NH}_{2}$ - terminal portion of the peptide. While the liberated $\mathrm{COOH}$-terminal fragments could not be identified (Figure 3 and Table I), the fact that this peptide, which begins at $\mathrm{V}_{1908}$, is cleaved by calpain suggests the presence of additional calpain sensitive sites near the $\mathrm{COOH}$-terminus of $\beta \mathrm{II}$ spectrin. Presumably, these are the sites that generate $\beta \mathrm{II}-\mathrm{BDP} 62$ and $\beta$ II-BDP58, or $\beta$ II-BDP220 and $\beta$ II-BDP215 from intact $\beta$ II spectrin (Table I \& Figure 8).

\section{Epitope specific antibodies recognize the calpain cleavage products of all and $\beta$ II spectrin}

With precise information on the sites of calpain cleavage, it is possible to prepare antibodies to the novel epitopes created by calpain cleavage. We have previously demonstrated the utility of such antibodies, prepared on the basis of our earlier determination of the sequences about the calpain cleavage site that generates $\alpha \mathrm{II}-\mathrm{BDP} 150$ and $\alpha \mathrm{II}-\mathrm{BDP} 150{ }^{\prime}(45,47)$; such antibodies enable the detection of minimal levels of aII-BDP150/150' in tissues and cells (29, 62). The specificity of two antibodies that detect either the new $\mathrm{COOH}$-terminus or the new $\mathrm{NH}_{2}{ }^{-}$ terminus generated by calpain cleavage of $\alpha$ II spectrin is shown in Figure 4. Native $\alpha$ II/ $\beta$ II spectrin was digested with either $\mu$-calpain, or with trypsin, and then analyzed by Western blotting with either $\alpha$-bdp1 antibody, prepared to the novel COOH-terminal sequence QQEVY, or $\alpha$-bdp2 antibody prepared to GMMPR-. Note the absence of reactivity of either antibody with intact spectrin, and the discrimination possible between a $150 \mathrm{kD} \alpha \mathrm{II}$ fragment generated by calpain $v s$. a similar sized fragment generated by trypsin. Antibody $\beta$-bdp1 was also prepared to the novel COOH-terminus o the $\beta$ III-BDP166 peptide. As with $\alpha$-bdp1 and $\alpha$ bdp2, $\beta$-bdp1 did not react with intact $\beta$ II spectrin. Interestingly, this antibody reacted only with $\beta$ II-BDP166, and not with $\beta$ II-BDP163 or $\beta$ II-BDP159, confirming the microsequencing studies indicating that the 163 and $159 \mathrm{kD}$ products derived from $\beta$ II-BDP166 by additional COOH-terminal cleavages.

\section{Glutamate/NMDA and maitotoxin activate distinct pathways of calpain cleavage in cultured cells}

To determine how the $\mathrm{Ca}^{++}$activation of calpain by two distinct pathways affects the pattern of spectrin cleavage in vivo, the response of various cells to either glutamate/NMDA stimulation or calcium loading (via maitotoxin) was evaluated. These results are shown in Figures 5, 6, and 7. In cells containing NMDA receptors, such as rat cortical or hippocampal neurons, glutamate stimulates the opening of gated $\mathrm{Ca}^{++}$channels, allowing the influx of extracellular $\mathrm{Ca}^{++}$. This process can activate long-term potentiation (reviewed in 63, 64). Figure 5A,B illustrates that brief exposure to glutamate stimulates calpain cleavage of aII but not $\beta$ II spectrin in cortical neurons, and that only $\alpha$ II-BDP150 (but not $\alpha$ II-BDP145) is generated by such stimulation. This activity is confined to a small pool of the total spectrin in the cell; the absence of aII-BDP145 generation implies that CaM is not active on spectrin during this period. Conversely, glutamate did not enhance spectrin cleavage in SH-SY5Y cells, a neuroblastoma line that lacks NMDA receptors (Figure 5C), demonstrating the indirect effect of glutamate on calpain mediated spectrin cleavage.

To better understand the sequential nature of NMDA-receptor stimulation of spectrin cleavage, the processing of spectrin in cultured rat hippocampal neurons was examined at early time points after glutamate or NMDA stimulation (Fig. 6). $\alpha$ II-BDP150' appeared as early as 4 to 
5 minutes after the addition of $50 \mu \mathrm{M}$ glutamate. The level of cleavage reached a meta-stable plateau after 90 minutes. After this point, the bdp 145 product began to appear, a cleavage that is only observed in vitro when CaM is bound to $\alpha$ II spectrin (Fig. 1). As shown in Figure 5A, the amount of cleaved $\alpha$ II spectrin induced in these experiments represents only a very small fraction of the total protein, and cleavage of $\beta I I$ spectrin at these early time-points was not detected (Fig. 5). In control experiments, MK801, a specific NMDA receptor channel blocker, completely blocked the glutamate-induced cleavage of spectrin (not shown), indicating that glutamate was activating calpain processing specifically through the NMDA receptor (NMDA$\mathrm{R})$, and not via other types of glutamate receptors such as the AMPA or Kainate receptors. Thus, $\mathrm{Ca}^{++}$entry through the activated NMDA-R channel stimulates within 3-5 minutes calpain proteolysis of a small pool of $\alpha \mathrm{II}-$ spectrin, and this process occurs without evidence of either CaM stimulation or $\beta I I$ spectrin cleavage. This apparent plateau in $\alpha$ II-spectrin cleavage without $\beta$ II-spectrin cleavage is transitory. Prolonged stimulation with NMDA receptor agonists or at levels that rapidly induce neurotoxicity induces the complete cleavage of both $\alpha \mathrm{II}$ and $\beta \mathrm{II}$ spectrin by calpain over a 12 hour period (Fig. 6 , inset).

Calcium entry into SH-SY5Y cells treated with maitotoxin in the presence of normal culture medium had quite a different effect on spectrin breakdown (Figure 7). Maitotoxin is a marine toxin that opens L-type voltage-sensitive and receptor-operated calcium channels in the plasma membrane. It specifically activates calpain but not caspase and induces non-apoptotic cell death $(65,66)$. Within 60 minutes of maitotoxin treatment, there is extensive calpain mediated cleavage of $\alpha$ II spectrin, as detected both by Pab-RAFA and by $\alpha$-bdp1 (Fig. 7A,B).

Interestingly, while the generation of the $\alpha$-bdp145 fragment (a marker of calmodulin action in vitro) is not appreciably delayed, there is delayed onset of proteolysis of $\beta I I$ spectrin. All of this breakdown can be attributed to calpain (vs. caspase), since it is totally inhibited by a calpain inhibitor (Fig. 7A, inset, lane 3) but not by a caspase inhibitor (Fig. 7A, inset, lane 4). These results suggest that a sequential $\alpha \mathrm{II} / \beta \mathrm{II}$ cleavage process similar to that we previously identified to be under the control of $\mathrm{CaM}$ in vitro (46) is active in vivo. Finally, in parallel experiments, the extent of cellular death was monitored after maitotoxin treatment by the ability of the cells to stain with Ethidium-1 (Fig. 7B). Progressive cell death occurs over the period in which aII and $\beta I I$ spectrin are being rapidly cleaved. While the correlation is not precise, it is noteworthy that while all $\alpha$ II spectrin is proteolyzed by 90 minutes, cell death continues to occur correlating with the onset and continued proteolysis of $\beta$ II spectrin.

\section{Discussion}

This report identifies five novel sites of calpain-catalyzed cleavage in $\alpha \mathrm{II}$ and $\beta \mathrm{II}$-spectrin; establishes that in vivo (as in vitro) the proteolysis of $\beta I I$ spectrin is trans-regulated by $\mathrm{CaM}$ binding to the $\alpha \mathrm{II}$ subunit; and establishes a correlation between $\beta \mathrm{II}$ spectrin proteolysis and conditions eliciting non-apoptotic cell death. These conclusions are supported by several lines of evidence: i) $\mathrm{NH}_{2}$-terminal microsequencing identifies a second calpain cleavage site in $\alpha$ II spectrin at $\mathrm{G}_{1230}$, immediately downstream of the primary calpain cleavage site at $\mathrm{Y}_{1176}$ and the $\mathrm{CaM}$ binding domain of $\alpha$ II-spectrin; ii) this site is only cleaved when $\mathrm{CaM}$ is bound; iii) microsequencing identifies a prominent $\mathrm{CaM}$ dependent cleavage site in $\beta \mathrm{II}$ spectrin at $\mathrm{Q}_{1440}$, and secondary cleavage sites at $\mathrm{S}_{1447}$ and $\mathrm{L}_{1482}$; iv) additional, less favorable, cleavages have been identified in $\beta$ II spectrin including a cleavage near the COOH-terminus that may include one $\left(\mathrm{A}_{2067}\right)$ previously identified (53); and $\mathrm{v}$ ) recombinant $\beta$ II spectrin peptides display identical calpain cleavage sites whose susceptibility (in the absence of a paired $\alpha$ II subunit) is $\mathrm{CaM}$ independent. These cleavages are summarized in Figure 8. Experiments in cultured cells using subunit or epitope-specific antibodies establish a close correspondence between the proteolytic products observed in vitro and those generated in vivo, and demonstrate that calpain cleavage of $\alpha$ II spectrin can be activated in responsive cells by physiologic receptors without cell death, such as by low-level stimulation of glutamate receptors. Presumably, the early and 
localized low-level cleavage of just $\alpha$ II spectrin occurs in response to specific signals in susceptible cells and allows for membrane receptor rearrangements. While the correlation of $\alpha$ II spectrin processing and/or calpain activation in response to low level stimulation has been variably noted in several previous studies $\left(9,18^{-21}, 67\right)$, the participation of $\beta I I$ spectrin cleavage in this process has gone unexamined. It is thus interesting that under conditions promoting glutamate toxicity, or actions directly inimical to the cell such as $\mathrm{Ca}^{++}$loading (e.g. by maitotoxin) (55), we consistently find both very high levels of spectrin proteolysis, as well as cleavage of both the $\alpha \mathrm{II}$ and $\beta \mathrm{II}$ subunits.

This study also highlights perhaps the clearest example yet of trans-regulation between the two spectrin subunits. Calmodulin binds exclusively to a single site in $\alpha$ II spectrin. In the presence of bound $\mathrm{CaM}$, new sites in $\alpha$ II spectrin $\left(\mathrm{G}_{1230}\right)$ and in $\beta \mathrm{II}$ spectrin $\left(\mathrm{Q}_{1440}, \mathrm{~S}_{1447}\right.$, and $\mathrm{L}_{1482}$ ) become susceptible to calpain, and the rate of calpain cleavage of $\beta \mathrm{II}$ spectrin is enhanced many fold. Since recombinant $\alpha$ II spectrin peptides are not readily cleaved at the $\mathrm{G}_{1230}$ bond (also see 48), it follows that CaM must create a new site favorable for cleavage by altering the tertiary conformation of $\alpha$ II spectrin about G1230., a finding consistent with the significant reordering of the 3-D structure of spectrin's calmodulin binding domain by bound CaM (51). Conversely, isolated $\beta$ II spectrin recombinant peptides are readily cleaved by calpain at the same site as in $\mathrm{CaM}$-loaded $\alpha \mathrm{II} / \beta \mathrm{II}$ spectrin. Based on the best available data for the alignment of the two subunits (68), the preferred sites of cleavage in $\alpha I I$ and $\beta I I$ spectrin appear to be adjacent in the heterodimer (Figure 8). Thus, while conformational distortion of $\beta$ II spectrin by $\mathrm{CaM}$ acting through the $\alpha$ II subunit cannot be rigorously excluded, we favor (on the principal of parsimony) the interpretation that calpain access to the susceptible $\beta \mathrm{II}$ cleavage site is blocked by $\alpha$ II spectrin in the intact heterodimer, and that this blockage is relieved by the conformational changes in $\alpha$ II spectrin elicited by $\mathrm{CaM}$ (or possibly by the secondary cleavage of $\alpha$ II-BDP150 to $\alpha$ II-BDP145). It is unlikely that the susceptibility of isolated $\beta$ II peptides derives from their failure to form a native-like structure because they exhibit a level of $\alpha$-helix consistent with intact spectrin ( $\approx 70 \%$ by CD measurement), and unlike other proteases the determinants of calpain-specificity reside not in a linear amino-acid sequence but rather in complex conformational determinants unlikely to be represented in a denatured peptide (48).

The correlation of $\beta$ II cleavage with cell-lethal manipulation is an interesting one. While glutamate or NMDA exposure of neurons may induce lethality, this is not an obligate effect, and at least in the short-term these compounds may activate long-term potentiation and synaptic remodeling without neuronal death $(12,21,69)$. The factors that determine whether glutamate exposed neurons survive or die are complex and incompletely understood, and include changes in nitrous oxide synthetase (70), protein kinase $\mathrm{C}$ (71), the level of intracellular $\mathrm{Ca}^{++}$and other cations $(72,73)$, and the their interaction with glial cells $(74,75)$. Our results suggest that the extent of $\beta$ II spectrin cleavage may be another determining factor. Previously we have established that $\alpha$ II spectrin cleavage by calpain modifies spectrin, such that it becomes a reversible actin cross-linking protein under the control of $\mathrm{Ca}^{++}$and $\mathrm{CaM}$ (54). The native (noncleaved) protein constitutively cross-links actin and is not modulated by $\mathrm{Ca}^{++}$or $\mathrm{CaM}$. Thus, by activating the calpain cleavage of $\alpha$ II spectrin, glutamate stimulation of neurons would be expected to convert a relatively fixed cortical spectrin-actin lattice into one dynamically regulated by $\mathrm{Ca}^{++}$and $\mathrm{CaM}$, presumably facilitating the changes in receptor organization required for long-term potentiation (76) and synaptic plasticity $(12,77)$. Conversely, cleavage of $\beta I I$ spectrin by calpain in vitro leads to irreversible disassembly of the spectrin-actin complex (54) and the loss of membrane anchoring sites (52), mirroring the in vivo disruption of the cortical spectrin-actin skeleton characteristic of hypoxic cells $(29,78)$, the early stages of apoptosis (in which both subunits of spectrin are simultaneously cleaved) (55), or the effects of intracellular calcium loading induced by maitotoxin in the experiments reported here. We hypothesize that these associations are more than coincidental, and suggest that the cleavage 
of $\beta$ II spectrin, whether by excessive activation of calpain (as in glutamate toxicity or maitotoxin treatment) or by the action of caspase during apoptosis (55), contributes to a degenerative process whereby the spectrin-actin skeleton, membrane integrity, and membrane protein organization are disrupted. It is also interesting to note that while in this model CaM acts as both a reversible regulator of skeletal plasticity, and the activator of $\beta I I$ spectrin cleavage by calpain (with consequential risk to the cell), it also acts at the same time to protect spectrin from cleavage by several executioner caspases (79). Thus, while activating susceptibility to calpain cleavage, CaM may dampen or abrogate certain apoptotic processes. The susceptibility of spectrin to calpain cleavage is also regulated by reversible phosphorylation of $\mathrm{Y}_{1176}$ (49, 50). Thus, the regulation of $\alpha$ II spectrin proteolysis appears to be a point of convergence of several signal transduction pathways. It will be important in future studies to determine the functional consequences of the various regulated cleavages described here, and whether cells can be rendered less susceptible to non-apoptotic cell death by specifically blocking of $\beta I I$ spectrin cleavage.

\section{Supplementary Material}

Refer to Web version on PubMed Central for supplementary material.

\section{Acknowledgments}

The authors thank Drs. Alan Harris, Christian Lombardo, and Mr. Paul Stabach, for providing several reagents and for assistance with the preparation of some constructs and antibodies.

This work supported by NIH grants R01-DK43812 and P01-NS35476 (Ment PI) to JSM and by a NRSA postdoctoral fellowship to SBG.

\section{Abbreviations}

$\alpha I I-B D P \quad \alpha I I-s p e c t r i n ~ b r e a k d o w n$ product

$\beta \mathrm{II}-\mathrm{BDP} \quad \beta \mathrm{II}-$ spectrin breakdown product

$\mathrm{CaM} \quad$ calmodulin

DMEM Dulbecco's Modified Eagle Medium

DTT dithiothreitol

MDL28170 carboxybenzyl-Val-Phe-H

MEM minimum essential medium

MTX maitotoxin

NMDA-R N-methyl-d-aspartate Receptor

$\mathrm{Pab}$ polyclonal antibody

PAGE polyacrylamide gel electrophoresis

PBS phosphate buffered saline

SDS sodium dodecyl sulfate

Z-D-DCB carbobenzoxy-Asp-CH2OC(O)-2,6-dichlorobenzene

\section{References}

1. Morrow, JS.; Rimm, DL.; Kennedy, SP.; Cianci, CD.; Sinard, JH.; Weed, SA. Handbook of Physiology. Hoffman, J.; Jamieson, J., editors. Oxford, London: 1997. p. 485-540. 
2. De Matteis MA, Morrow JS. Spectrin tethers and mesh in the biosynthetic pathway. J Cell Sci 2000;113:2331-2343. [PubMed: 10852813]

3. Bennett V, Baines AJ. Spectrin and ankyrin-based pathways: metazoan inventions for integrating cells into tissues. Physiol Rev 2001;81:1353-92. [PubMed: 11427698]

4. Deng H, Lee JK, Goldstein LS, Branton D. Drosophila development requires spectrin network formation. J Cell Biol 1995;128:71-9. [PubMed: 7822424]

5. Peters LL, Birkenmeier CS, Barker JE. Fetal compensation of the hemolytic anemia in mice homozygous for the normoblastosis (nb) mutation. Blood 1992;80:2122-7. [PubMed: 1391963]

6. Fox JE. Transmembrane signaling across the platelet integrin glycoprotein IIb-IIIa. Ann N Y Acad Sci 1994;714:75-87. [PubMed: 8017793]

7. Jesaitis AJ, Bokoch GM, Tolley JO, Allen RA. Lateral segregation of neutrophil chemotactic receptors into actin- and fodrin-rich plasma membrane microdomains depleted in guanyl nucleotide regulatory proteins. Journal Cell Biology 1988;107:921-928.

8. Lynch G, Baudry M. The biochemistry of memory: A new and specific hypothesis. Science 1984;224:1057-1063. [PubMed: 6144182]

9. Bednarski E, Vanderklish P, Gall C, Saido TC, Bahr BA, Lynch G. Translational suppression of calpain I reduces NMDA-induced spectrin proteolysis and pathophysiology in cultured hippocampal slices. Brain Res 1995;694:147-57. [PubMed: 8974639]

10. Bahr BA, Kessler M, Rivera S, Vanderklish PW, Hall RA, Mutneja MS, Gall C, Hoffman KB. Stable maintenance of glutamate receptors and other synaptic components in long-term hippocampal slices. Hippocampus 1995;5:425-39. [PubMed: 8773255]

11. Vanderklish P, Saido TC, Gall C, Arai A, Lynch G. Proteolysis of spectrin by calpain accompanies theta-burst stimulation in cultured hippocampal slices. Brain Res Mol Brain Res 1995;32:25-35. [PubMed: 7494460]

12. Faddis BT, Hasbani MJ, Goldberg MP. Calpain activation contributes to dendritic remodeling after brief excitotoxic injury in vitro. J Neurosci 1997;17:951-9. [PubMed: 8994050]

13. Dosemeci A, Reese TS. Effect of calpain on the composition and structure of postsynaptic densities. Synapse 1995;20:91-7. [PubMed: 7624834]

14. Sheppard AM, Wu JE, Staubli U, Perlmutter LS. Changes in calpain and brain spectrin immunoreactivity accompany sprouting in the deafferented hippocampus. Synapse 1993;15:239-42. [PubMed: 8278900]

15. Lee A, Morrow JS, Fowler VM. Caspase remodeling of the spectrin membrane skeleton during lens development and aging. J Biol Chem 2001;276:20735-42. [PubMed: 11278555]

16. Kamal A, Ying Y, Anderson RG. Annexin VI-mediated loss of spectrin during coated pit budding is coupled to delivery of LDL to lysosomes. J Cell Biol 1998;142:937-47. [PubMed: 9722607]

17. Fox JE, Taylor RG, Taffarel M, Boyles JK, Goll DE. Evidence that activation of platelet calpain is induced as a consequence of binding of adhesive ligand to the integrin, glycoprotein IIb-IIIa. J Cell Biol 1993;120:1501-7. [PubMed: 8449989]

18. Siman R, Noszek JC. Excitatory amino acids activate calpain I and induce structural protein breakdown in vivo. Neuron 1988;1:279-287. [PubMed: 2856162]

19. del Cerro S, Arai A, Kessler M, Bahr BA, Vanderklish P, Rivera S, Lynch G. Stimulation of NMDA receptors activates calpain in cultured hippocampal slices. Neurosci Lett 1994;167:149-52. [PubMed: 8177514]

20. Manev H, Favaron M, Siman R, Guidotti A, Costa E. Glutamate neurotoxicity is independent of calpain I inhibition in primary cultures of cerebellar granule cells. J Neurochem 1991;57:1288-95. [PubMed: 1680162]

21. Di Stasi AM, Gallo V, Ceccarini M, Petrucci TC. Neuronal fodrin proteolysis occurs independently of excitatory amino acid-induced neurotoxicity. Neuron 1991;6:445-454. [PubMed: 1848081]

22. Seubert P, Lee K, Lynch G. Ischemia triggers NMDA receptor-linked cytoskeletal proteolysis in hippocampus. Brain Res 1989;492:366-70. [PubMed: 2546656]

23. Arai A, Vanderklish P, Kessler M, Lee K, Lynch G. A brief period of hypoxia causes proteolysis of cytoskeletal proteins in hippocampal slices. Brain Res 1991;555:276-80. [PubMed: 1933340] 
24. Hong SC, Lanzino G, Goto Y, Kang SK, Schottler F, Kassell NF, Lee KS. Calcium-activated proteolysis in rat neocortex induced by transient focal ischemia. Brain Res 1994;661:43-50. [PubMed: 7834383]

25. Lee KS, Frank S, Vanderklish P, Arai A, Lynch G. Inhibition of proteolysis protects hippocampal neurons from ischemia. Proc Natl Acad Sci U S A 1991;88:7233-7. [PubMed: 1871130]

26. Rami A, Krieglstein J. Protective effects of calpain inhibitors against neuronal damage caused by cytotoxic hypoxia in vitro and ischemia in vivo. Brain Res 1993;609:67-70. [PubMed: 8508322]

27. Bartus RT, Hayward NJ, Elliott PJ, Sawyer SD, Baker KL, Dean RL, Akiyama A, Straub JA, Harbeson SL, Li Z, et al. Calpain inhibitor AK295 protects neurons from focal brain ischemia. Effects of postocclusion intra-arterial administration. Stroke 1994;25:2265-70. [PubMed: 7974554]

28. Doctor RB, Bennett V, Mandel LJ. Degradation of spectrin and ankyrin in the ischemic rat kidney. American Journal of Physiology 1993;264:C1003-13. [PubMed: 8386446]

29. Glantz, SB.; Morrow, JS. Tissue Oxygen Deprivation: Developmental, Molecular and Integrated Function. Haddad, GG.; Lister, G., editors. Marcel Dekker, Inc.; New York: 1996. p. 153-192.

30. Gaudio KM, Thulin G, Siegel NJ. Glycolysis is not responsible for the tolerance of immature renal tubules to anoxia. Pediatr Res 1996;40:457-61. [PubMed: 8865284]

31. Iizuka K, Kawaguchi H, Yasuda H. Calpain is activated during hypoxic myocardial cell injury. Biochem Med Metab Biol 1991;46:427-31. [PubMed: 1793619]

32. Iizuka K, Kawaguchi H, Yasuda H, Kitabatake A. The role of calcium activated neutral protease on myocardial cell injury in hypoxia. Jpn Heart J 1992;33:707-15. [PubMed: 1289600]

33. Iizuka K, Kawaguchi H, Kitabatake A. Effects of thiol protease inhibitors on fodrin degradation during hypoxia in cultured myocytes. J Mol Cell Cardiol 1993;25:1101-9. [PubMed: 8283473]

34. Yoshida K, Sorimachi Y, Fujiwara M, Hironaka K. Calpain is implicated in rat myocardial injury after ischemia or reperfusion. Jpn Circ J 1995;59:40-8. [PubMed: 7752444]

35. Siman R, Noszek JC, Kegerise C. Calpain I activation is specifically related to excitatory amino acid induction of hippocampal damage. J Neurosci 1989;9:1579-90. [PubMed: 2542478]

36. Seubert P, Larson J, Oliver M, Jung MW, Baudry M, Lynch G. Stimulation of NMDA receptors induces proteolysis of spectrin in hippocampus. Brain Research 1988;460:189-194. [PubMed: 2905922]

37. Bi X, Chang V, Siman R, Tocco G, Baudry M. Regional distribution and time-course of calpain activation following kainate-induced seizure activity in adult rat brain. Brain Res 1996;726:98-108. [PubMed: 8836550]

38. Mucke L, Masliah E, Campbell IL. Transgenic models to assess the neuropathogenic potential of HIV-1 proteins and cytokines. Curr Top Microbiol Immunol 1995;202:187-205. [PubMed: 7587363]

39. Toggas SM, Masliah E, Mucke L. Prevention of HIV-1 gp120-induced neuronal damage in the central nervous system of transgenic mice by the NMDA receptor antagonist memantine. Brain Res 1996;706:303-7. [PubMed: 8822372]

40. Sasaki M, Uchiyama J, Ishikawa H, Matsushita S, Kimura G, Nomoto K, Koga Y. Induction of apoptosis by calmodulin-dependent intracellular Ca2+ elevation in CD4+ cells expressing gp 160 of HIV. Virology 1996;224:18-24. [PubMed: 8862395]

41. Vanags DM, Porn-Ares MI, Coppola S, Burgess DH, Orrenius S. Protease involvement in fodrin cleavage and phosphatidylserine exposure in apoptosis. J Biol Chem 1996;271:31075-85. [PubMed: 8940103]

42. Nath R, Raser KJ, McGinnis K, Nadimpalli R, Stafford D, Wang KK. Effects of ICE-like protease and calpain inhibitors on neuronal apoptosis. Neuroreport 1996;8:249-55. [PubMed: 9051790]

43. Nath R, Raser KJ, Stafford D, Hajimohammadreza I, Posner A, Allen H, Talanian RV, Yuen P, Gilbertsen RB, Wang KK. Non-erythroid alpha-spectrin breakdown by calpain and interleukin 1 beta-converting-enzyme-like protease(s) in apoptotic cells: contributory roles of both protease families in neuronal apoptosis. Biochem J 1996;319:683-90. [PubMed: 8920967]

44. Harris AS, Morrow JS. Proteolytic processing of human brain alpha spectrin (fodrin): identification of a hypersensitive site. J Neurosci 1988;8:2640-51. [PubMed: 3074159]

45. Harris AS, Croall D, Morrow JS. The calmodulin-binding site in fodrin is near the site of calciumdependent protease-I cleavage. J Biol Chem 1988;263:15754-15761. [PubMed: 2844821] 
46. Harris AS, Croall DE, Morrow JS. Calmodulin regulates fodrin susceptibility to cleavage by calciumdependent protease I. J Biol Chem 1989;264:17401-17408. [PubMed: 2551900]

47. del Lacoste M-C, Lewis CE, White CL, Morrow JS. Immunocytochemical evidence of accelerated spectrin proteolysis in hippocampus from alzheimer disease patients. Neuroscience 1992;18:558. (abstract).

48. Stabach PR, Cianci CD, Glantz SB, Zhang Z, Morrow JS. Site-directed mutagenesis of alpha II spectrin at codon 1175 modulates its mu-calpain susceptibility. Biochemistry 1997;36:57-65. [PubMed: 8993318]

49. Nicolas G, Fournier CM, Galand C, Malbert-Colas L, Bournier O, Kroviarski Y, Bourgeois M, Camonis JH, Dhermy D, Grandchamp B, Lecomte MC. Tyrosine phosphorylation regulates alpha II spectrin cleavage by calpain. Mol Cell Biol 2002;22:3527-36. [PubMed: 11971983]

50. Nedrelow JH, Cianci CD, Morrow JS. c-Src binds alpha II spectrin's Src homology 3 (SH3) domain and blocks calpain susceptibility by phosphorylating Tyr1176. J Biol Chem 2003;278:7735-41. [PubMed: 12446661]

51. Simonovic M, Zhang Z, Cianci CD, Steitz TA, Morrow JS. Structure of the calmodulin alpha IIspectrin complex provides insight into the regulation of cell plasticity. J Biol Chem. 2006 in press.

52. Hu RJ, Bennett V. In vitro proteolysis of brain spectrin by calpain I inhibits association of spectrin with ankyrin-independent membrane binding site(s). Journal Biological Chemistry 1991;266:1820018205.

53. Lofvenberg L, Backman L. Calpain-induced proteolysis of beta-spectrins. FEBS Lett 1999;443:89_ 92. [PubMed: 9989581]

54. Harris AS, Morrow JS. Calmodulin and calcium-dependent protease I coordinately regulate the interaction of fodrin with actin. Proc Nat Acad Sci (USA) 1990;87:3009-3013. [PubMed: 2326262]

55. Wang KK, Posmantur R, Nath R, McGinnis K, Whitton M, Talanian RV, Glantz SB, Morrow JS. Simultaneous degradation of alphaII- and betaII-spectrin by caspase 3 (CPP32) in apoptotic cells. J Biol Chem 1998;273:22490-7. [PubMed: 9712874]

56. Bennett V. Purification of brain analogs of red blood cell membrane skeletal proteins: Ankyrin, protein 4.1 (synapsin), spectrin, and spectrin subunits. Methods in Enzymology 1986;134:55-69. [PubMed: 2950299]

57. Harris AS, Green LAD, Ainger KJ, Morrow JS. Mechanisms of cytoskeletal regulation (1): Functional differences correlate with antigenic dissimilarity in human brain and erythrocyte spectrin. Biochim Biophys Acta 1985;830:147-158. [PubMed: 2410030]

58. Lombardo CR, Weed SA, Kennedy SP, Forget BG, Morrow JS. $\beta I I-S p e c t r i n$ (fodrin) and $\beta \mathrm{I} \Sigma 2$ Spectrin (muscle) Contain NH2- \& COOH-terminal Membrane Association Domains (MAD1 \& MAD2). J Biol Chem 1994;269:29212-29219. [PubMed: 7961888]

59. Harris AS, Anderson JP, Yurchenco PD, Green LAD, Ainger KJ, Morrow JS. Mechanisms of cytoskeletal regulation: Functional and antigenic diversity in human erythrocyte and brain beta spectrin. J Cellular Biochem 1986;30:51-70. [PubMed: 2420811]

60. Harlow, E.; Lane, D. Antibodies: A laboratory manual. Cold Spring Harbor Laboratory; Cold Spring Harbor: 1988.

61. Laemmli UK. Cleavage of structural proteins during the assembly of the head of bacteriophage T4. Nature (London) 1970;227:680-685. [PubMed: 5432063]

62. Glantz SB, Friedman JE, Haddad GG, Morrow JS. Calpain cleavage of $\alpha$ II spectrin in primary cortical and hippocampal cultures detected by cleavage specific antibodies. Molecular Biology of the Cell 1995;6:371a. (abstract). [PubMed: 7626804]

63. Miyamoto E, Fukunaga K. A role of $\mathrm{Ca} 2+/$ calmodulin-dependent protein kinase II in the induction of long-term potentiation in hippocampal CA1 area. Neurosci Res 1996;24:117-22. [PubMed: 8929917]

64. Cain DP. LTP, NMDA, genes and learning. Curr Opin Neurobiol 1997;7:235-42. [PubMed: 9142751]

65. Wang KKW, Nath R, Raser KJ, Hajimohammadreza I. Maitotoxin induces calpain activation in SHSY5Y neuroblastoma cells and cerebrocortical cultures. Arch Biochem Biophys 1996;331:208-14. [PubMed: 8660700] 
66. Zhao X, Pike BR, Newcomb JK, Wang KK, Posmantur RM, Hayes RL. Maitotoxin induces calpain but not caspase-3 activation and necrotic cell death in primary septo-hippocampal cultures. Neurochem Res 1999;24:371-82. [PubMed: 10215511]

67. Adamec E, Beermann ML, Nixon RA. Calpain I activation in rat hippocampal neurons in culture is NMDA receptor selective and not essential for excitotoxic cell death. Brain Res Mol Brain Res 1998;54:35-48. [PubMed: 9526039]

68. Speicher DW, DeSilva TM, Speicher KD, Ursitti JA, Hembach P, Weglarz L. Location of the human red cell spectrin tetramer binding site and detection of a related "closed" hairpin loop dimer using proteolytic footprinting. J Biol Chem 1993;268:4227-35. [PubMed: 8440706]

69. Bear MF, Malenka RC. Synaptic plasticity: LTP and LTD. Curr Opin Neurobiol 1994;4:389-99. [PubMed: 7919934]

70. Wang JY, Chi SI, Wang JY, Hwang CP, Wang JY. Effects of various nitric oxide synthase inhibitors on NMDA-induced neuronal injury in rat cortical neurons. Chin J Physiol 1996;39:227-33. [PubMed: 9058007]

71. Durkin JP, Tremblay R, Chakravarthy B, Mealing G, Morley P, Small D, Song D. Evidence that the early loss of membrane protein kinase $\mathrm{C}$ is a necessary step in the excitatory amino acid-induced death of primary cortical neurons. J Neurochem 1997;68:1400-12. [PubMed: 9084410]

72. Chen QX, Perkins KL, Choi DW, Wong RKS. Secondary activation of a cation conductance is responsible for NMDA toxicity in acutely isolated hippocampal neurons. J Neurosci 1997;17:40326. [PubMed: 9151719]

73. Chidekel AS, Friedman JE, Haddad GG. Anoxia-induced neuronal injury: role of Na+ entry and Na +-dependent transport. Exp Neurol 1997;146:403-13. [PubMed: 9270051]

74. Dugan LL, Bruno VM, Amagasu SM, Giffard RG. Glia modulate the response of murine cortical neurons to excitotoxicity: glia exacerbate AMPA neurotoxicity. J Neurosci 1995;15:4545-55. [PubMed: 7540679]

75. Auld DS, Robitaille R. Glial cells and neurotransmission: an inclusive view of synaptic function. Neuron 2003;40:389-400. [PubMed: 14556716]

76. Lynch G, Kessler M, Arai A, Larson J. The nature and causes of hippocampal long-term potentiation. Progress in Brain Research 1990;83:233-250. [PubMed: 2168058]

77. Park JS, Bateman MC, Goldberg MP. Rapid alterations in dendrite morphology during sublethal hypoxia or glutamate receptor activation. Neurobiol Dis 1996;3:215-27. [PubMed: 8980022]

78. Molitoris BA, Dahl R, Hosford M. Cellular ATP depletion induces disruption of the spectrin cytoskeletal network. Am J Physiol 1996;271:F790-8. [PubMed: 8898008]

79. Rotter B, Kroviarski Y, Nicolas G, Dhermy D, Lecomte MC. AlphaII-spectrin is an in vitro target for caspase-2, and its cleavage is regulated by calmodulin binding. Biochem J 2004;378:161-8. [PubMed: 14599290]

80. Cianci CD, Morrow JS. Complete cDNA sequence of human fetal brain aII spectrin with a novel alternative splice. GenBank U83867. 1997

81. Hu R-J, Watanabe M, Bennett V. Characterization of human brain cDNA encoding the general isoform of $\beta$-spectrin. Journal Biological Chemistry 1992;267:18715-18722.

82. Smith DB, Davern KM, Board PG, Tiu WU, Garcia EG, Mitchell GF. Mr 26,000 antigen of Schistosoma japonicum recognized by resistant WEHI 129/J mice is a parasite glutathione Stransferase [published erratum appears in Proc Natl Acad Sci U S A 1987 Sep;84(18):6541]. Proc Natl Acad Sci U S A 1986;83:8703-7. [PubMed: 3095841] 


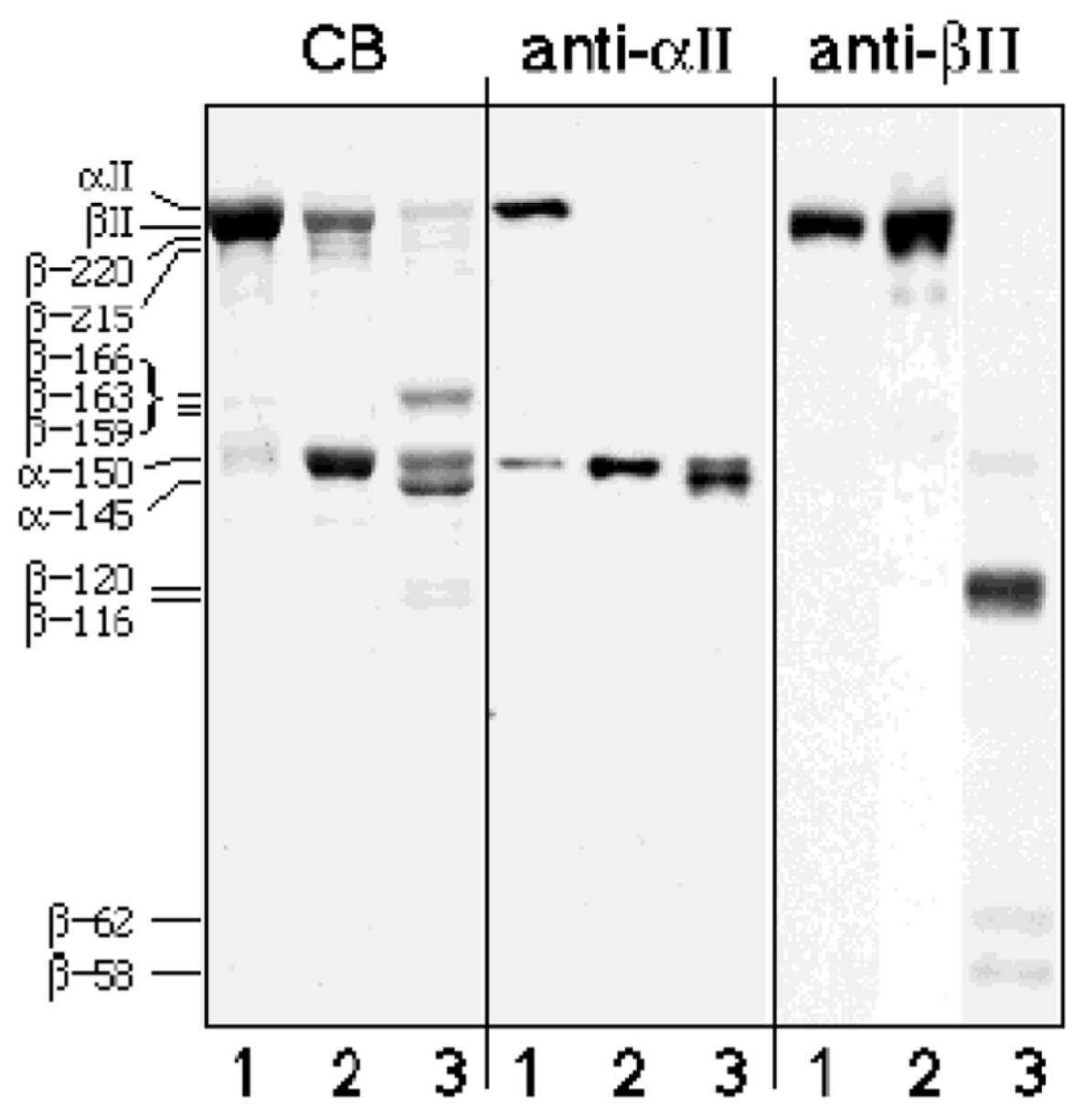

Figure 1. Calmodulin enhances $\mu$-calpain cleavage of both subunits of $\alpha I I / \beta I I$ spectrin $C B$ ) Coomassie Blue-stained 7\% SDS-PAGE analysis of purified $\alpha$ II/ $\beta$ II spectrin from bovine brain (lane 1) incubated with $\mu$-calpain (molar $\mathrm{E} / \mathrm{S}=1: 18$ ) in the absence (lane 2) or presence (lane 3) of $5 \mu \mathrm{M}$ calmodulin and $150 \mu \mathrm{M} \mathrm{Ca}^{++}$for 15 minutes at $25^{\circ} \mathrm{C}$. Note the accentuation of digestion when calmodulin is present. Prominent digestion products are apparent at 166, 150, 145, and 120/116 (fainter bands) kD. Anti-aII) Western blot analysis of the same samples with PAb RAF-A, directed against $\alpha$ II spectrin. Note the additional $\alpha$ II spectrin cleavage product at $\approx 145 \mathrm{kD}$ induced by CaM. Anti- $\boldsymbol{\beta I I}$ ) Western blot of same samples examined with $\mathrm{PAb} 10 \mathrm{D}$, which is directed against $\beta$ II spectrin, repeat unit 13 (residue 1676) to $\mathrm{L}_{2204}$ (near the COOH-terminus). This antibody does not recognize the prominent $\beta$ II spectrin BDP's at $\approx 159-166 \mathrm{kD}$, but detects the BDP's at $\approx 116-120 \mathrm{kD}$ and at $62 / 58 \mathrm{kD}$ derived from the $\mathrm{COOH}$-terminal portions of $\beta \mathrm{II}$ spectrin. Note that there is minimal cleavage of $\beta \mathrm{II}$ spectrin in the absence of CaM. The apparent molecular weights and the subunit of origin of each observed digestion product are indicated. 


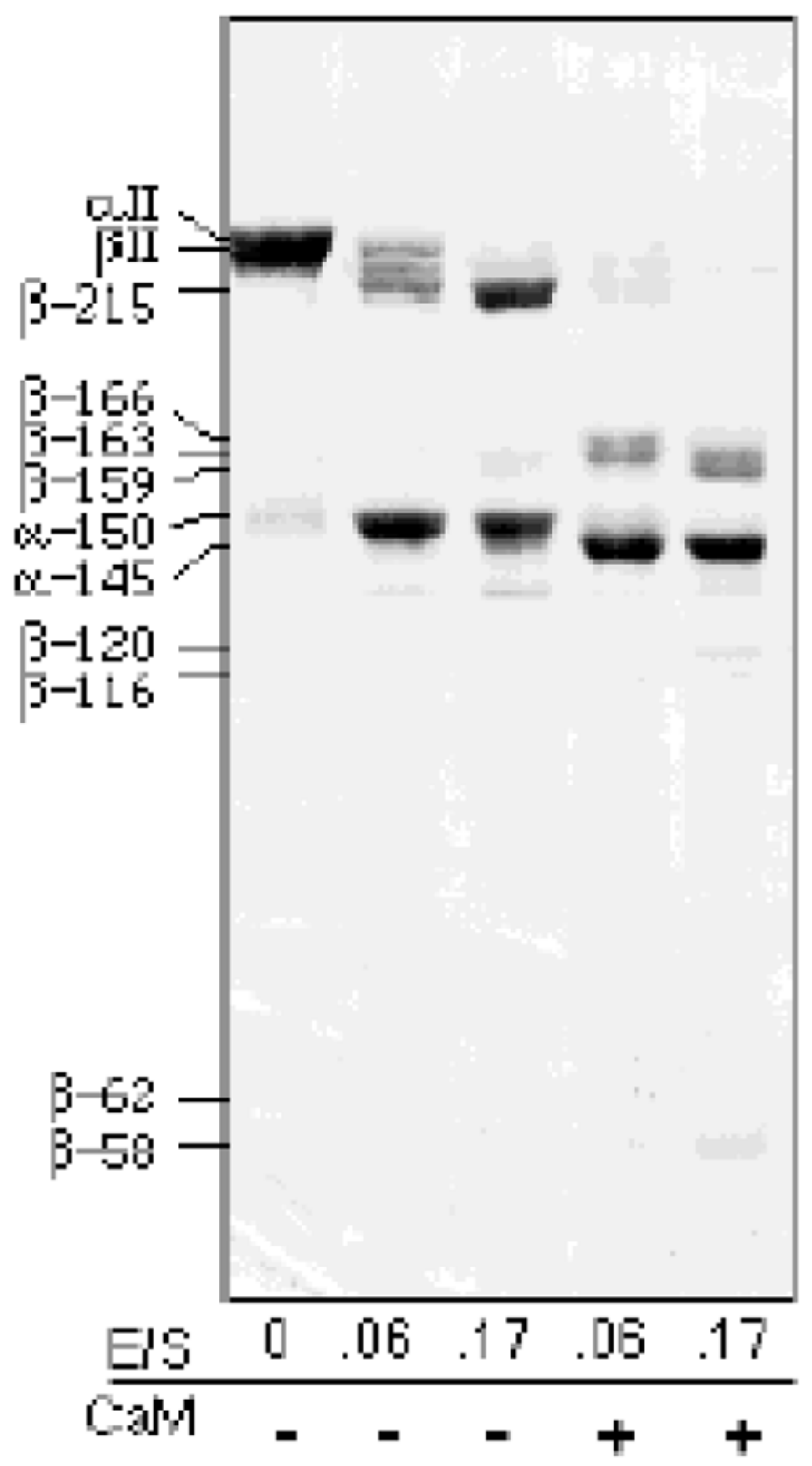

Figure 2. At high enzyme to substrate ratios, there is limited cleavage of $\beta$ II spectrin in the absence of CaM

Calpain digestion of $\alpha \mathrm{II} / \beta \mathrm{II}$ spectrin $(11 \mu \mathrm{g} / \mathrm{lane})$ was carried out for 45 minutes at $25^{\circ} \mathrm{C}$ at the molar $\mathrm{E} / \mathrm{S}$ ratios indicated, with or without $\mathrm{CaM}$ and $0.15 \mathrm{mM} \mathrm{Ca}^{++}$. At high $\mathrm{E} / \mathrm{S}$ ratios, a $\approx 215 \mathrm{kD} \beta \mathrm{II}$ spectrin BDP was generated in the absence of $\mathrm{CaM}$. In the presence of $\mathrm{CaM}$, an additional $\beta$ II BDP of $\approx 159 \mathrm{kD}$ was generated. These results were independent of $\mathrm{Ca}^{++}$ concentration, within the range of $0.15 \mathrm{mM}$ to $1.5 \mathrm{mM}$ total calcium (data not shown). 

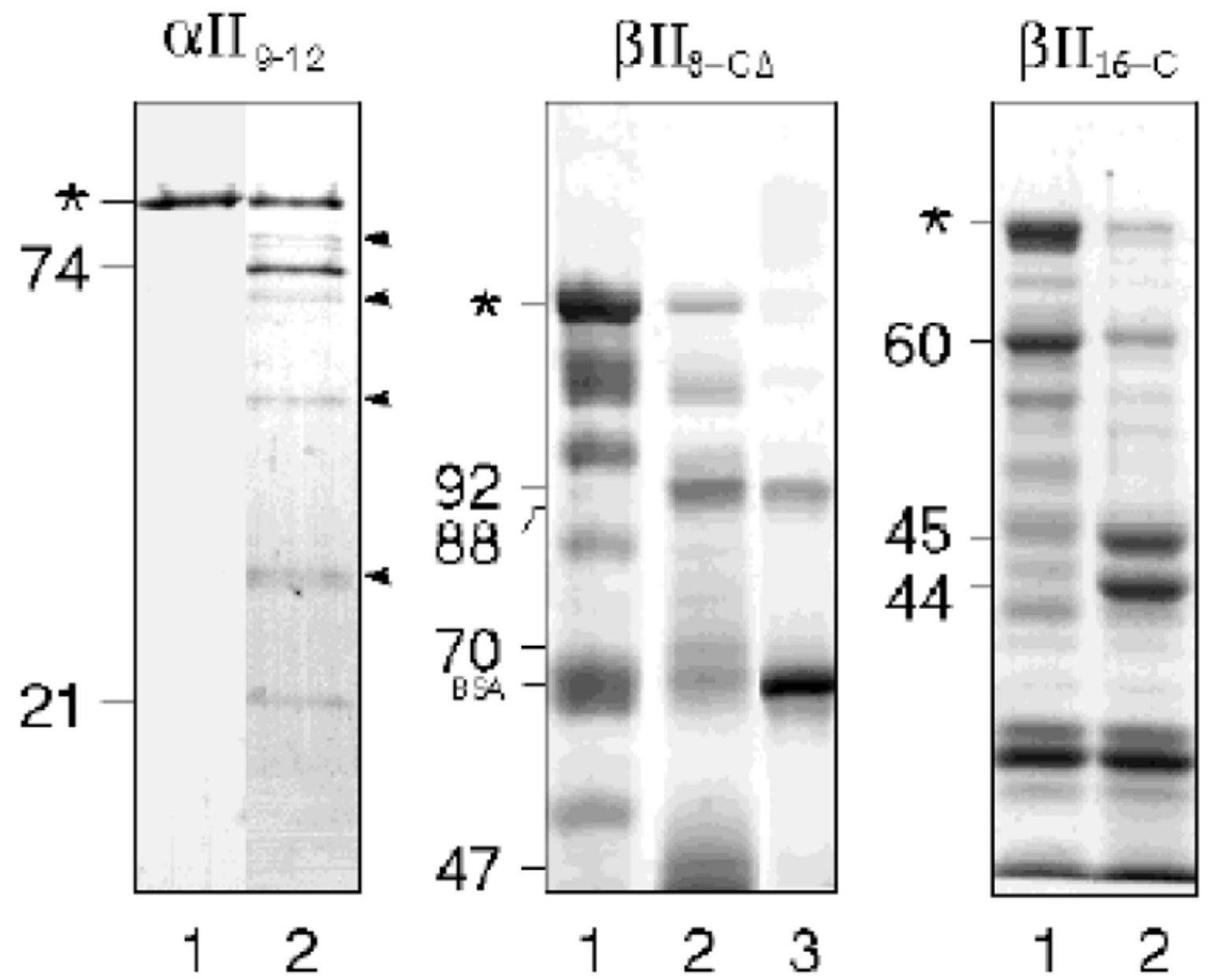

Figure 3. Calpain cleavage of recombinant spectrin peptides

Purified recombinant GST-fusion peptides encompassing the designated regions of $\alpha$ II or $\beta$ II spectrin were digested with $\mu$-calpain for 15 minutes at $25^{\circ} \mathrm{C}$. Lane 1 ,starting peptide; lane 2 , peptide digested with calpain. For $\beta \mathrm{II}_{8-\mathrm{C} \Delta}$, the glutathione-S-transferase-containing digestion fragments were removed by incubation with glutathione-agarose beads in the presence of bovine serum albumin, and the remaining material (the GST-free 92 and $88 \mathrm{kD}$ fragments) were analyzed (lane 3). The major detected digestion products for each peptide are indicated (with apparent size in $\mathrm{kD}$ ), as is the position of bovine serum albumin (BSA). Asterisks identify full-length fusion peptides. Arrowheads point to autolytic fragments of calpain. Coomassie Blue-stained SDS polyacrylamide gels are shown. Duplicate analyses were transferred to Immobilon-P and the $\mathrm{NH}_{2}$-terminal sequence of the major BDP's determined (Table I). 
A
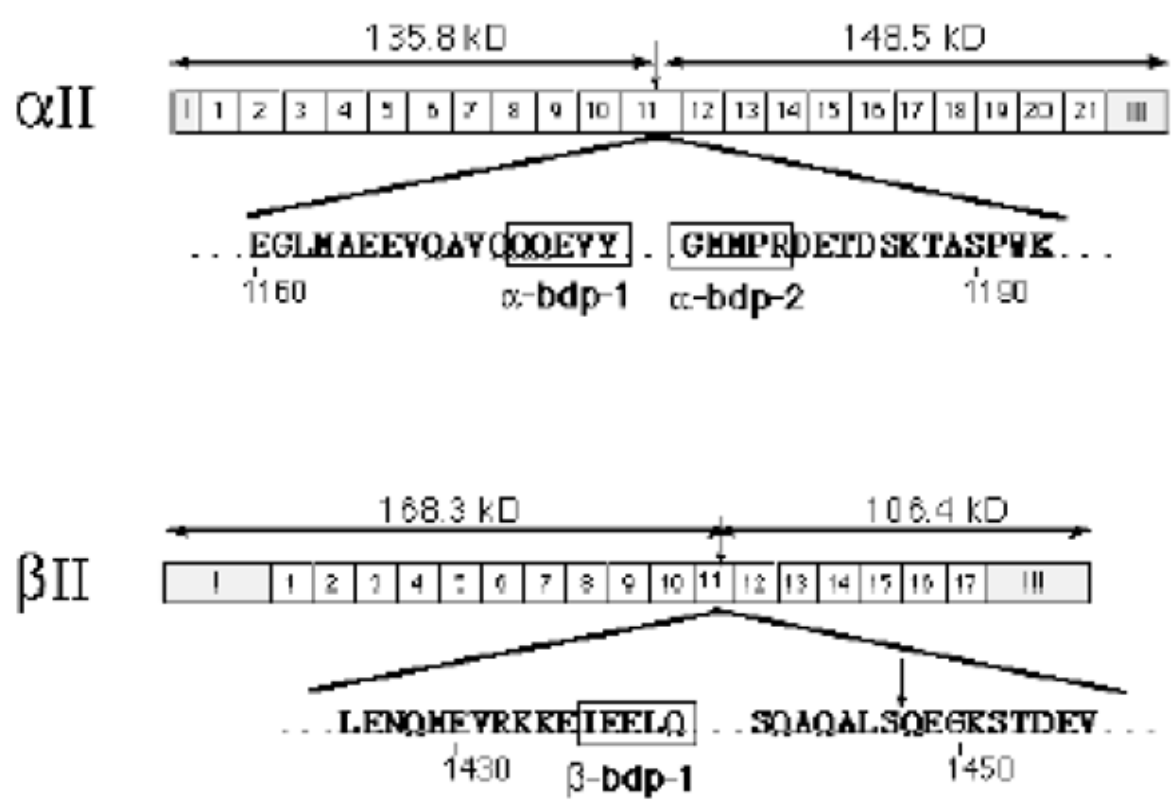

B

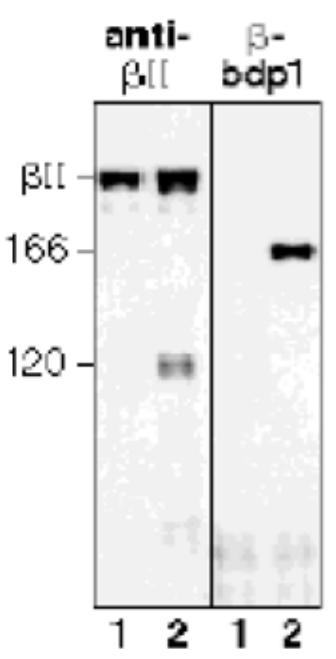

Figure 4. Antibodies raised to the novel termini generated in spectrin by $\mu$-calpain digestion recognize only the calpain processed $\alpha$ II and $\beta I I$ subunits

(A) Synthetic peptides representing the novel terminal five residues generated by $\mu$-calpain cleavage of either $\alpha$ II or $\beta$ II spectrin (boxes) were conjugated to KLH, and used to generate rabbit or chicken PAb antibodies to the novel epitopes created by the cleavages $(29,47)$. The epitopes used to generate the antibodies $\alpha$-BDP1, $\alpha$-BDP2, and $\beta$-BDP1, and their loci with respect to the overall structure of spectrin, are depicted. (B) Western blots using either PAb RAF-A (anti- $\alpha$ II), PAb-10D (anti- $\beta$ II), or the cleavage specific antibodies listed above. Lane 1 , intact spectrin (with some endogenous degradation); lane 2, $\mu$-calpain cleaved spectrin; lane 3 , trypsin cleaved spectrin. The weak reactivity with the $\alpha$-BDP1 and $\alpha$-BDP2 antibodies with 
the intact spectrin and in trypsin-digested spectrin is due to trace $\mu$-calpain cleaved material contaminating the original preparation. The PAb $10 \mathrm{D}$ used to immunoblot $\beta \mathrm{II}$ spectrin here only recognizes the $\mathrm{COOH}$-terminal half of $\beta \mathrm{II}$ spectrin (see text), and thus detects $\beta$ II-BDP120 but not $\beta$ II-BDP166, which is recognized by $\beta$-BDP1. Note the absence of reactivity of the BDP antibodies to intact $\alpha \mathrm{II} / \beta \mathrm{II}$ spectrin. 

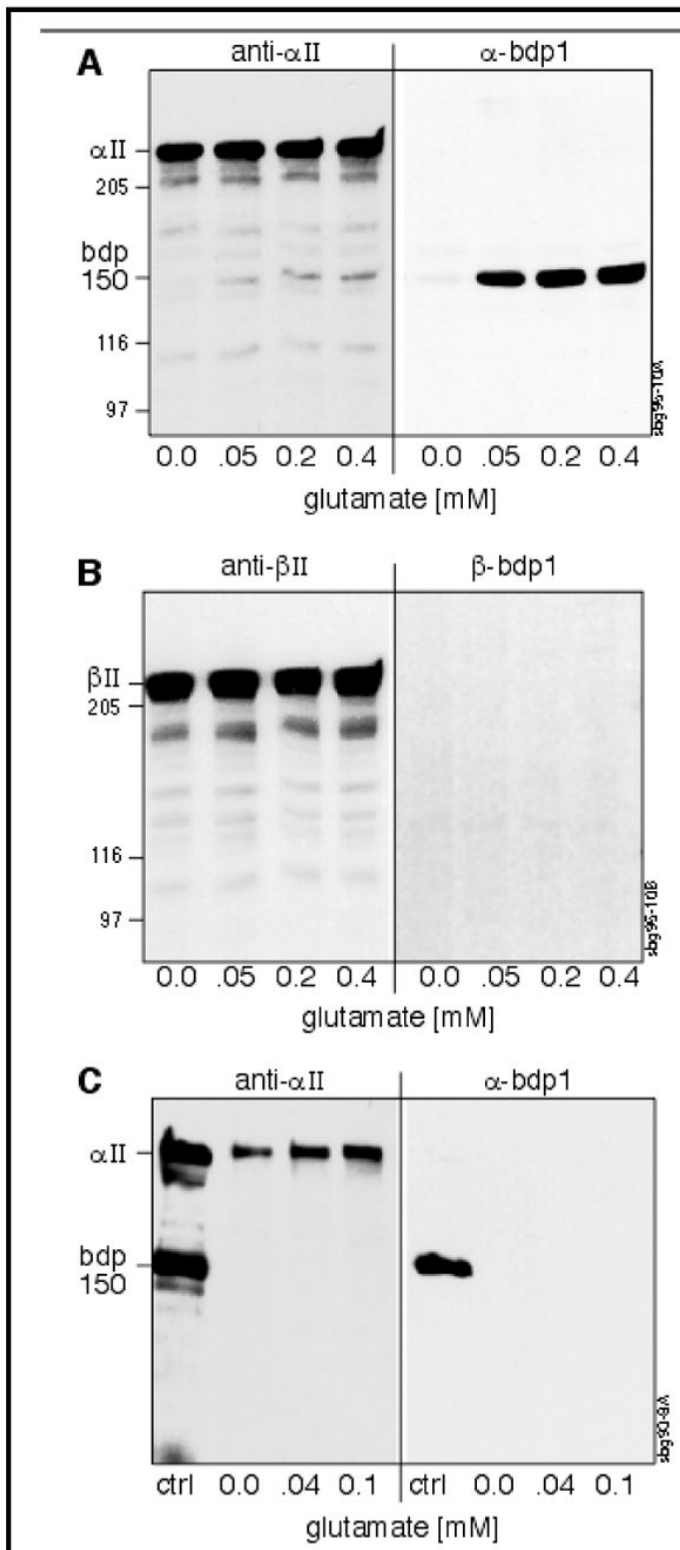

Figure 5. Glutamate stimulates calpain cleavage of $\alpha$ II but not $\beta I I$ spectrin in responsive cells $(\mathbf{A}, \mathbf{B})$ Rat cortical neurons, or (C) neuroblastoma SH-SY5Y cells, were incubated for 20 or $45 \mathrm{~min}$. respectively in the presence of increasing concentrations of glutamate. Equivalent numbers of cells at each glutamate concentration were harvested and examined by SDS-PAGE and Western blotting with either Pab RAFA (anti- $\alpha$ II) or $\alpha$-BDP-1 (A,C) or Pab 10D (anti$\beta \mathrm{II}) / \beta$-BDP-1 (B). Each lane contains $50 \mu \mathrm{g}$ total cellular protein. A control lane (ctrl) contains purified spectrin (with some endogenous degradation products). The size (kD) of major BDP's, as well as several MW markers, are shown. Note that with glutamate stimulation of cortical neurons, there is activation of $\alpha$ II-spectrin cleavage by calpain, but no calpain cleavage of $\beta$ II 
spectrin. Conversely, in cells that lack significant levels of glutamate receptors (SH-SY5Y), glutamate stimulation does not activate the cleavage of spectrin. 

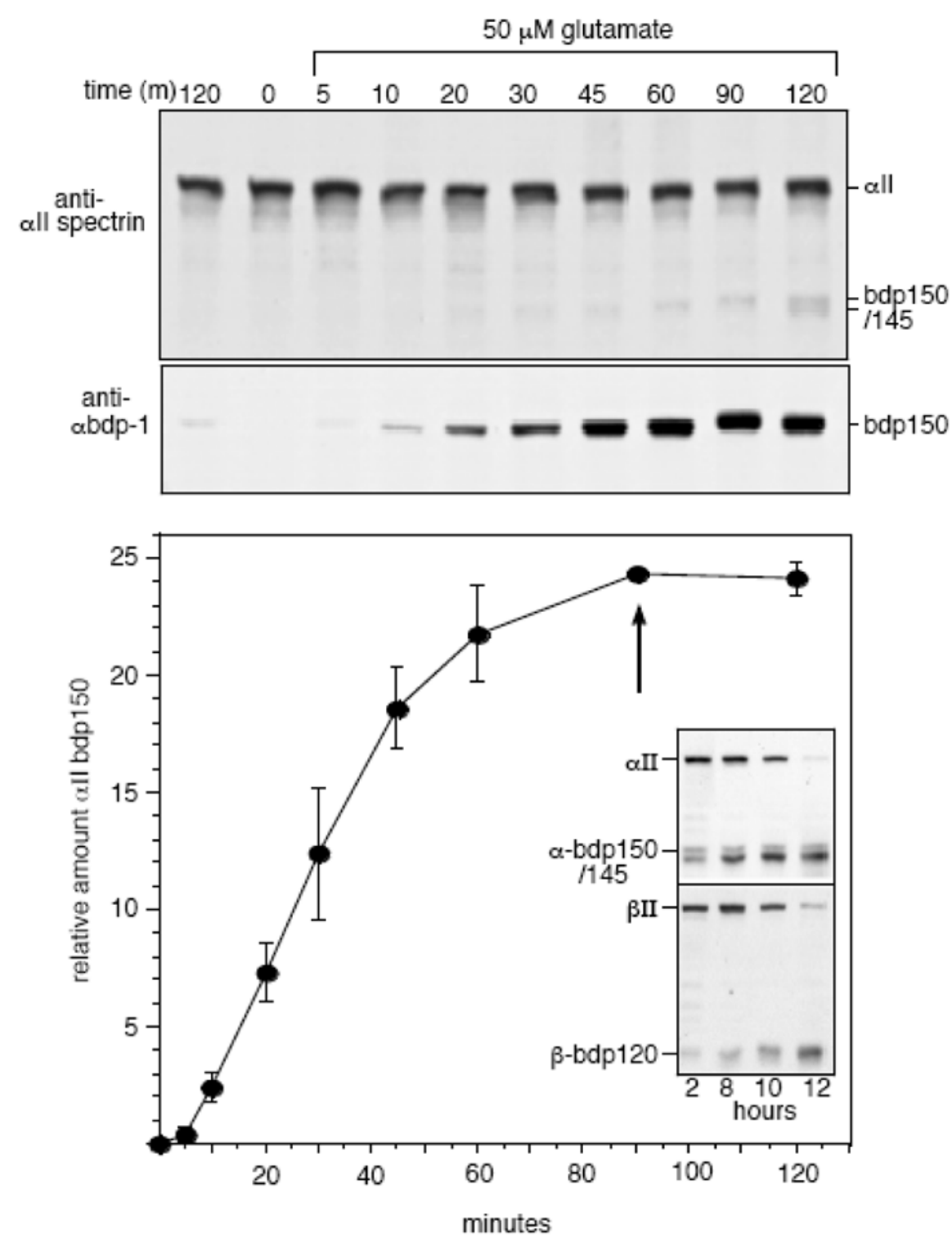

Figure 6. NMDA receptor stimulation selectively activates the calpain-processing of $\alpha$ II spectrin at early time points in neurons

(top)Rat hippocampal cultures were incubated with $50 \mu \mathrm{M}$ glutamate for the times indicated ( 0 to 120 minutes). Control cells were incubated for either 0 minutes or for 120 or 60 minutes with vehicle alone or with MK801, a specific blocker of the NMDA receptor. Samples were examined for $\alpha \mathrm{II}$ and $\beta \mathrm{II}$ spectrin cleavage by Western blotting. There was no significant $\beta \mathrm{II}$ spectrin cleavage under these conditions (see Fig. 5); MK801 completely blocked all cleavage (not shown). Densitometic analysis of the $\alpha$-bdp1 blots revealed a biphasic response in $\alpha$ II spectrin cleavage, with a 3-5 min. lag before the onset of proteolysis, and a meta-stable plateau at about $90 \mathrm{~min}$. After this time point (arrow), the $\alpha$-bdp-145 proteolytic product began to 
appear, a putative marker of $\mathrm{CaM}$ stimulation of $\alpha$ II spectrin cleavage. In parallel experiments with cortical neurons carried out for longer periods after NMDA stimulation (inset), $\beta$ II spectrin cleavage began to accelerate at about 2 hours, and the calpain-mediated proteolysis of both subunits progressed to completion over a $12 \mathrm{~h}$. period. The graph presents mean values $\pm \mathrm{SD}$, $\mathrm{N}=3$. 


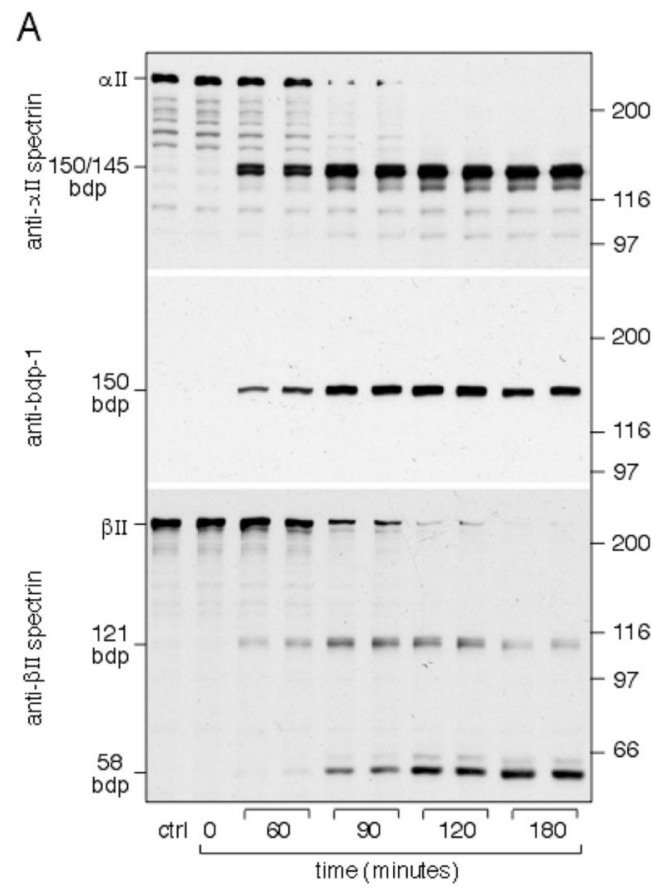

B

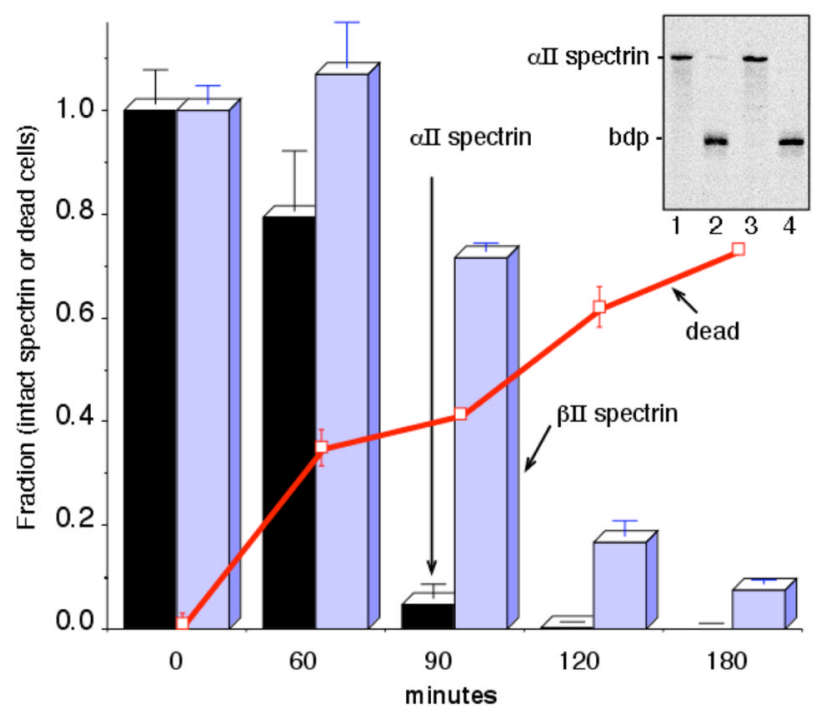

Figure 7. Maitotoxin treatment of SH-SY5Y cells leads to sequential cleavage of $\alpha \mathrm{II} / \mathrm{\beta II}$ spectrin and cell death

(A) Cultured SH-SY5Y cell were treated with $0.04 \mathrm{nM}$ maitotoxin, and the time-course of spectrin breakdown monitored by Western blotting after SDS-PAGE analysis of cell lysates ( $20 \mu \mathrm{g} / \mathrm{lane}$ ) with Pab-RAFA (anti- $\alpha$ II spectrin); $\alpha$-bdp-1 antibody; and Pab-10D (anti- $\beta$ II spectrin). Control cells were incubated for three hours without maitotoxin (ctrl). Duplicate experiments are shown for each time point. Note the rapid breakdown of $\alpha$ II spectrin vs. the delayed loss of $\beta$ II spectrin. The positions of MW markers $(\div 1000)$ are depicted on the right; prominent bdp's are marked on the left. (B) Densitometric evaluation of the extent of spectrin breakdown of the gels shown in (A). The extent of maitotoxin-induced cell death was also 
evaluated in parallel experiments of maitotoxin treated cells, as measured by flow cytometry after Ethidium-1 staining. Data points are the mean \pm SD of three determinations. Background cell death (non-viable cells at $\mathrm{t}=0$ ) was subtracted from all points. (Inset) Western blot with Pab RAFA of SH-SY5Y cells after $0.03 \mathrm{nM}$ maitotoxin treatment, \pm inhibition of calpain or caspase. The maitotoxin induced cleavage of spectrin was entirely inhibited by the calpain inhibitor calpeptin, but not by the caspase inhibitor Z-D-DCB. Lane 1, control SH-SY5Y cells; lane 2, cells after $3 \mathrm{hrs}$ of maitotoxin treatment; lane 3, $3 \mathrm{hrs}$. maitotoxin + calpeptin; lane 4 , 3hrs. maitotoxin + caspase inhibitor. 


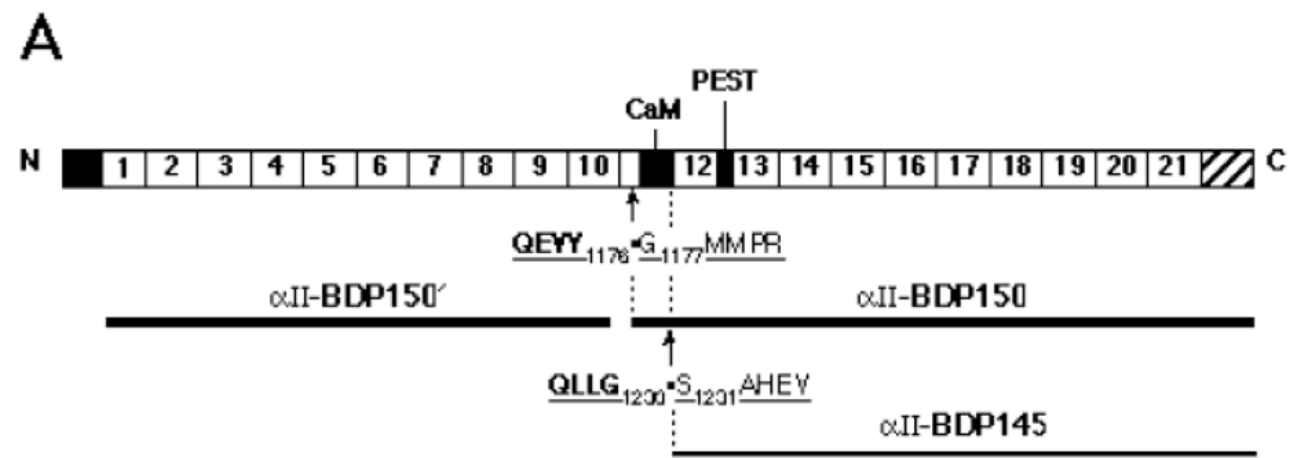

B

Anti- $\beta$-spectrin-10D
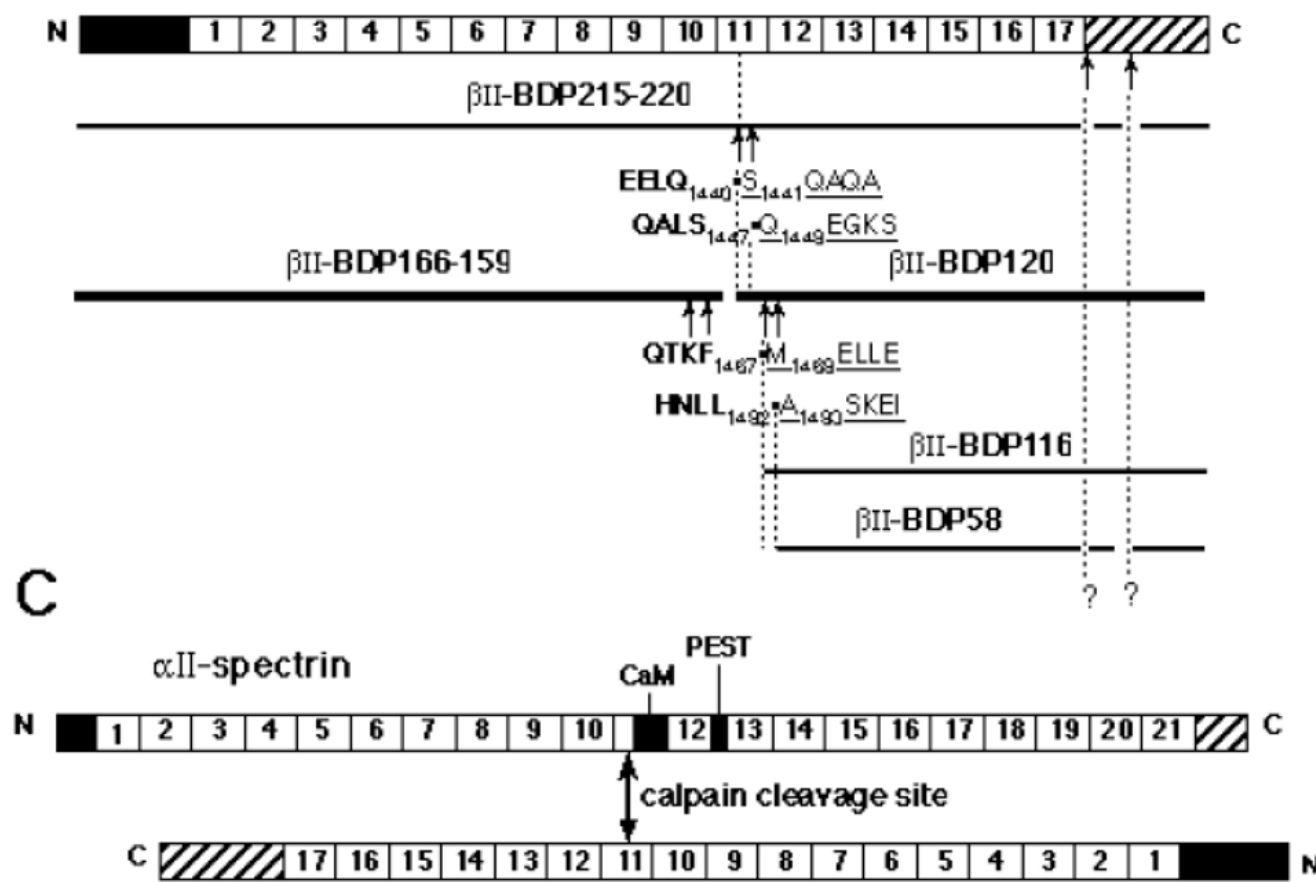

ßII-spectrin

Figure 8. Summary of the calpain cleavage sites in $\alpha \mathrm{II} / \beta \mathrm{II}$ spectrin

Schematic representation of the structure of $\alpha$ II-spectrin and $\beta I I-s p e c t r i n$ illustrates the sites of cleavage and size of the proteolytic fragments. Each subunit consists of three structural domains; domain II contains $21(\alpha)$ or $17(\beta)$ structural repeats. Non-homologous sequence domains are present at either end of each subunit. (A) Cartoon of $\alpha$ II spectrin subunit with calpain cleavage sites indicated. The calmodulin binding domain and a region of PEST sequence is indicated; each homologous repeat unit is numbered. (B) Cartoon of $\beta I I-s p e c t r i n$ showing the sites of calpain digestion. (C) Schematic illustration of the relationship of the major digestion sites in the $\alpha \beta$-spectrin heterodimer. The structural depiction of the spectrin dimer and the alignment of the two subunits with respect to each other is adapted from Speicher et al. (68). Note the alignment of the major $\alpha \mathrm{II}$ and $\beta$ II calpain cleavage sites in the two subunits. 
Table I

Major $\mu$-calpain generated spectrin fragments.

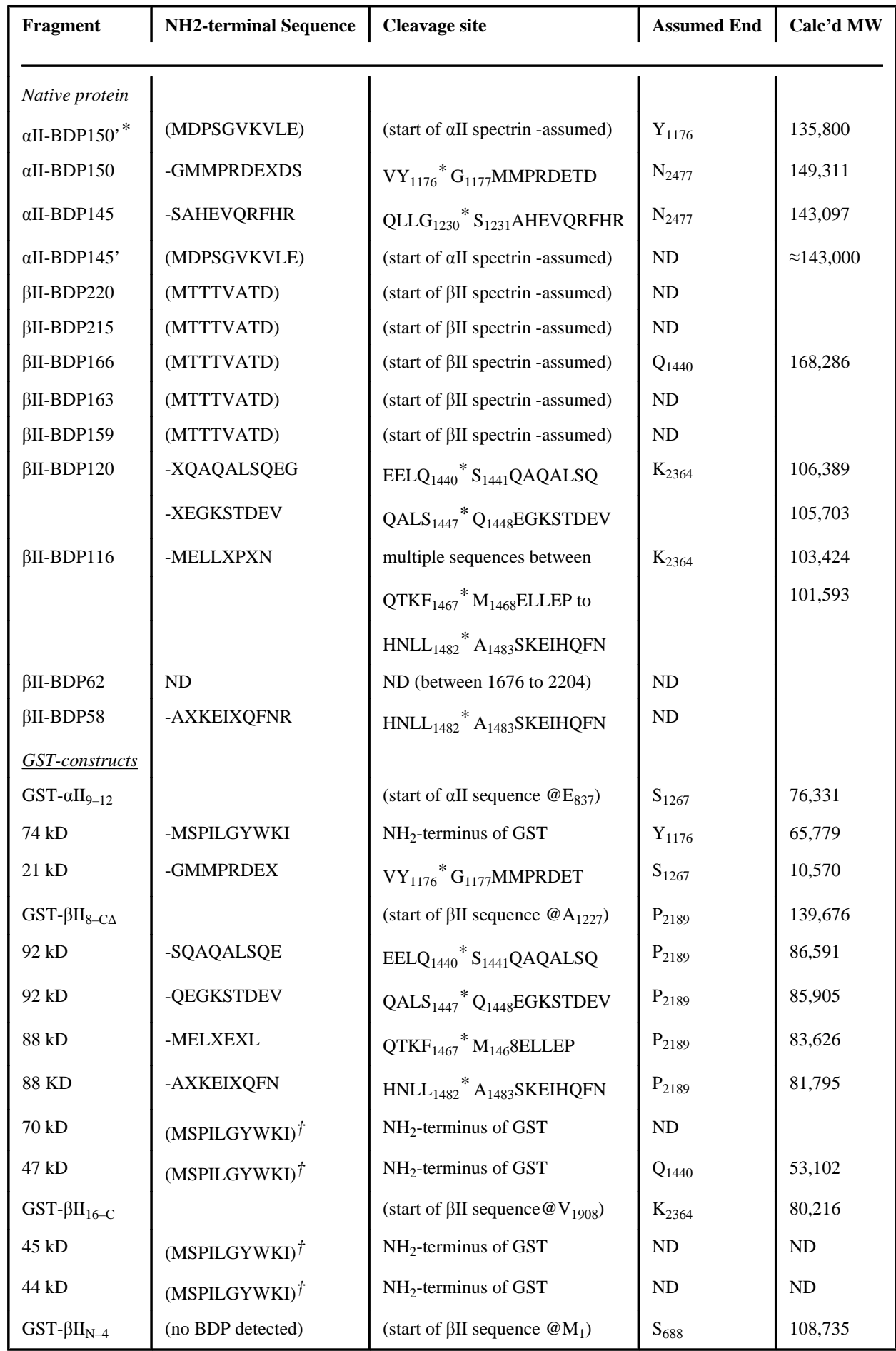

All digestion's were carried out in vitro. Sequence numbering based on $\alpha$ II $\Sigma 1$ spectrin (GenBank \#U83867, ref.80) and $\beta I I$ spectrin (GenBank \#M96803, ref. 81). Sequence of GST26 from Schistosomajaponica (82). 
* Two cleavage products are present in the $\alpha$ II-BDP150 band, representing $\alpha$ II residues 1 to 1176 (calculated MW 135,800) and 1177 to 2477 (45). Only one of these is detected by microsequencing since the NH2-terminus of spectrin is methylated. In separate experiments, we have observed that milli-calpain also cleaves at this site (data not shown).

${ }^{\dagger}$ Not sequenced; end is assumed based on retention of these peptides on glutathione affinity column (see text). ND - not determined.

X- unidentified residue 